\title{
Azadinium poporum from the Argentine Continental Shelf, Southwestern Atlantic, produces azaspiracid-2 and azaspiracid-2 phosphate
}

\author{
Urban Tillmann $^{\mathrm{a}, *}$, C. Marcela Borel ${ }^{\mathrm{b}}$, Facundo Barrera ${ }^{\mathrm{c}}$, Rubén Lara ${ }^{\mathrm{c}}$, \\ Bernd Krock ${ }^{a}$, Gastón O. Almandoz ${ }^{\mathrm{d}}$, Matthias Witt ${ }^{\mathrm{e}}$, Nicole Trefault ${ }^{\mathrm{f}}$ \\ ${ }^{a}$ Alfred Wegener Institute, Am Handelshafen 12, D-27570 Bremerhaven, Germany \\ ${ }^{\mathrm{b}}$ Instituto Geológico del Sur (CONICET - Universidad Nacional del Sur), Departamento de Geología, Laboratorio de Palinología, San Juan 670, \\ 8000 Bahía Blanca, Argentina \\ ${ }^{\mathrm{c}}$ Instituto Argentino de Oceanografía, Biogeoquímica Marina, IADO - CONICET, Camino la Carrindanga km 7,5 c.c. 804, B8000FWB, Bahía Blanca, Argentina \\ ${ }^{\mathrm{d}}$ División Ficología, Facultad de Ciencias Naturales y Museo, Universidad Nacional de La Plata, Paseo del Bosque s/n, B1900FWA, La Plata, Argentina \\ e Bruker Daltonik GmbH, Fahrenheitstr. 4, 28359 Bremen, Germany \\ ${ }^{\mathrm{f}}$ Centro de Genómica y Bioinformática, Universidad Mayor, Camino La Pirámide 5750, Huechuraba, Santiago, Chile
}

\section{A R T I C L E I N F O}

\section{Article history:}

Received 5 August 2015

Received in revised form 2 November 2015

Accepted 2 November 2015

\section{Keywords:}

Azadinium

Azaspiracids

Southwestern Atlantic

Argentina

\begin{abstract}
A B S T R A C T
The marine dinophycean genus Azadinium has been identified as the primary source of azaspiracids (AZA), a group of lipophilic phycotoxins known to accumulate in shellfish. Blooms of Azadinium in the southern Atlantic off Argentina have been described from the 1990s, but due to a lack of cultures, the diversity of South-Atlantic Azadinium has not yet been fully explored and their toxin production potential is completely unknown. During a spring 2010 research cruise covering the El Rincón (ER) estuarine system (North Patagonian coast, Argentina, Southwestern Atlantic) a search was conducted for the presence of Azadinium. Although neither Azadinium cells nor AZA in field plankton samples were detected, 10 clonal strains of Azadinium poporum were successfuly established by incubation of sediment samples. Argentinean A. poporum were more variable in size and shape than the type description but conformed to it by the presence of multiple pyrenoids with starch sheath, in plate pattern and arrangement, and in the position of the ventral pore located on the left side of the pore plate. In contrast to all previous description of A. poporum, isolates of the Argentinean A. poporum possessed a distinct field of pores on the second antapical plate. Conspecificity of the Argentinean isolates with A. poporum was confirmed by molecular phylogeny of concatenated ITS and LSU rDNA sequences, where all Argentinean isolates together with some Chinese A. poporum strains formed a well-supported ribotype clade within $A$. poporum. All isolates produced AZA with the same profile, consisting of AZA-2 as the major compound and, to a lesser extent, its phosphated form. This is the first report of a phosphated marine algal toxin. This first confirmation of the presence of AZA producing Azadinium in the Argentinean coastal area underlines the risk of AZA shellfish contamination episodes in the Southwestern Atlantic region.
\end{abstract}

(c) 2015 Elsevier B.V. All rights reserved.

\section{Introduction}

Harmful algal blooms and accumulation of phycotoxins in marine organisms pose a serious risk for human health (Glibert et al., 2005). Among the many known toxins of microalgal origin, azaspiracids (AZA) are a relatively new class of lipophilic compounds responsible for Azaspiracid Shellfish Poisoning

\footnotetext{
* Corresponding author.

E-mail address: urban.tillmann@awi.de (U. Tillmann).
}

(AZP). Azaspiracids were first recognized in the 1990s following an outbreak of human illness in the Netherlands that was associated with ingestion of blue mussels cultivated in Killary Harbour, Ireland (McMahon and Silke, 1996). The polyether toxins found to be present in this shellfish batch were subsequently identified and named azaspiracids (Satake et al., 1998; Nicolaou et al., 2006). Since then, AZA contamination of mussels above the European Union's regulatory level of $0.16 \mathrm{mg}$ AZA per $\mathrm{kg}$ mussel meat has been a recurrent and major problem in Ireland (Salas et al., 2011). This serious situation of high AZA levels in shellfish in Ireland seem to be exceptional, but over the last 15 years, AZA have 
been documented in shellfish from many coastal regions of western Europe (James et al., 2002; Braña Magdalena et al., 2003; Furey et al., 2003; Amzil et al., 2008), northern Africa (Taleb et al., 2006; Elgarch et al., 2008), China (Yao et al., 2010), and North America (Trainer et al., 2013). In addition, AZA have been found in Japanese sponges (Ueoka et al., 2009) and Scandinavian crabs (Torgersen et al., 2008). Within the southern hemisphere, AZA have been detected in New Zealand (Smith et al., 2015) and there are reports from South America as well. Azaspiracids were found in Chile in shellfish (Álvarez et al., 2010; López-Rivera et al., 2010) and in plankton samples from the Pacific (Trefault et al., 2011). An Azadinium-like flagellate was recently reported by Proenca et al. (2014) from the south west Atlantic off Brazil, and the presence of low levels of AZA in shellfish has been recently detected in Argentinean waters (Turner and Goya, 2015).

Whereas the chemistry of the toxins and various aspects of the toxicology and pharmacology were quite well known (Hess et al., 2014; Twiner et al., 2014), the planktonic source remained elusive until in 2007 the small dinoflagellate, Azadinium spinosum, was unambiguously identified as a new species and as the primary source of AZA (Tillmann et al., 2009). Stimulated by this finding, a number of subsequent studies have revealed a high biodiversity of Azadinium, and a total of ten species are currently known (Tillmann et al., 2014a). Not all species of Azadinium produce toxins. Azaspiracids have been detected in the type species $A$. spinosum (Krock et al., 2009), in A. dexteroporum (Percopo et al., 2013), and new AZA have been detected in Azadinium poporum and in the closely related species Amphidoma languida (Krock et al., 2012), which together with Azadinium is combined in the family Amphidomataceae (Tillmann et al., 2012a).

All but one Azadinium species have been described from European waters (North Sea, North Atlantic, Mediterranean) (Tillmann et al., 2009, 2010, 2011, 2012b, 2014a; Percopo et al., 2013), the exception being $A$. dalianense, which has been described from the China Sea (Luo et al., 2013). Species of Azadinium are generally small, inconspicuous, and thus difficult to detect and to identify by regular light microscopy. Reliable records are thus based on the troublesome procedure of isolating, cultivating and fully characterizing local strains (in terms of morphology and molecular information) or are based on records of single specimens detected by electron microscopy of plankton samples. A compilation of all such available Azadinium records clearly shows that knowledge of the biogeography of the genus currently is rather limited and patchy, but nevertheless indicates that species of Azadinium have a global distribution (Tillmann et al., 2014c).

A low level of AZA in two shellfish samples from western South Atlantic was recently reported (Turner and Goya, 2015), supporting the notion that Azadinium is present in this area. In fact, a species of Azadinium had been described to form dense spring blooms in northern shelf waters off Argentina as early as 1990 and 1991 (Akselman and Negri, 2012), almost 15 year before the genus was erected. As shown by light microscopy (LM) and scanning electron microscopy (SEM) the species in question clearly had the Azadinium plate tabulation pattern and possessed a small antapical spine and was thus designated as Azadinium cf. spinosum. However, DNA samples and toxin measurements from these blooms were lacking, and for a final species designation, a few yet unresolved morphological details (e.g. presence of a ventral pore) of the Argentinean species needed to be clarified. Very recently, a retrospective description of a third bloom of the same species in 1998 was published (Akselman et al., 2014). Furthermore, additional cruise and time series data of the Argentinean Sea indicate a rather wide spatial distribution of Azadinium encompassing the northern Argentine and southern Uruguayan shelf including the mouth of Rio de la Plata (Akselman et al., 2014).
Whereas the presence of Azadinium in Argentina is established, there is a lack of detailed morphological, molecular, and toxinological studies characterising the present species. It was thus the aim to use a research cruise of the R/V "Puerto Deseado" in 2010 to specifically search for the presence of Azadinium and to establish cultures for a detailed characterization.

Recurrent blooms of Azadinium in 1990, 1991, and 1998 (Akselman and Negri, 2012; Akselman et al., 2014) provided indications that cyst beds and cyst hatching may provide an important inoculum for local Azadinium populations. A number of dinoflagellates are known to produce cysts, mainly as a dormant, zygotic stage of their life cycle (Pfiester and Anderson, 1987). Such cysts can accumulate in the sediment, hatch after a dormant period and may thus act as "seed banks" with great ecological importance for bloom initiation. Knowledge on the life cycle and cyst formation of Azadinium is quite incomplete. Among species of Azadinium, cyst-like cells have been observed for only two species, A. polongum (Tillmann et al., 2012b) and Azadinium poporum (Gu et al., 2013). Successful isolation of $A$. poporum by incubating sediment samples (Potvin et al., 2012; Gu et al., 2013) is evidence for the presence of benthic resting stages in this species. Therefore, on the cruise sediment samples were taken in order to search for cysts of Azadinium and to use sediment in hatching experiments to obtain cultures of Azadinium.

The present study presents detailed morphological, molecular and toxinological characterization of ten isolates of Azadinium poporum obtained from incubating sediment samples from the El Rincón (ER) estuarine system, North Patagonian coast.

\section{Materials and methods}

\subsection{Field campaign}

\subsubsection{Sampling}

Samples were taken during a research cruise on board the $\mathrm{R} / \mathrm{V}$ "Puerto Deseado" (CONICET-MINDEF, Argentina) during the austral spring in October 2010. The cruise covered the ER estuarine system, a shallow Frontal System of northern Patagonia, western South Atlantic, $39-42^{\circ} \mathrm{S}, 60-64^{\circ} \mathrm{W}$ of approximately $10,000 \mathrm{~km}^{2}$ (Fig. 1). Most of the study area is shallow, the water depth at the sampling sites varying from 5 to $60 \mathrm{~m}$. At all stations continuous profiles of temperature and salinity (CTD) were determined (Sea Bird model 911 plus with General Oceanic rosette; calibrated to a final precision 0.05 in salinity and $0.02{ }^{\circ} \mathrm{C}$ in temperature). Oceanographic data were obtained in collaboration with the Instituto Nacional de Investigación y Desarrollo Pesquero (INIDEP). Depth and off shore distance were also measured. Water samples were collected at 3 and $10 \mathrm{~m}$ depth from Niskin bottles. Aliquots of $100 \mathrm{~mL}$ of each depth were fixed with acidic Lugol's solution ( $1 \%$ final concentration) for qualitative and quantitative plankton analysis. For phycotoxin analysis, subsamples from Niskin bottles were pre-screened through a $20 \mu \mathrm{m}$ mesh-size Nitex sieve and $1.5 \mathrm{~L}$ of the filtrate from each depth was mixed. Samples were filtered under gentle vacuum through $3 \mu \mathrm{m}$ pore-size polycarbonate filters (Millipore, Eschborn, Germany). Filters were stored in $50 \mathrm{~mL}$ centrifuge tubes (Sarstedt, Nümbrecht, Germany) at $-10{ }^{\circ} \mathrm{C}$ until analysis. Surface sediment samples were obtained by means of a pipette from the upper half centimeter, including the flocculent layer, of sediments collected by a Van Veen grab sampler during the Cruise at 21 stations. The samples were stored under nitrogen and sealed with parafilm in dark plastic bottles and kept at $4{ }^{\circ} \mathrm{C}$ to prevent cyst germination. Two sets of samples were obtained from the same grab sample of each station, one for the analysis of the organic-walled dinoflagellate cyst assemblages and the other for dinoflagellate cyst hatching experiments. The sediments selected for cysts hatching experiments were 


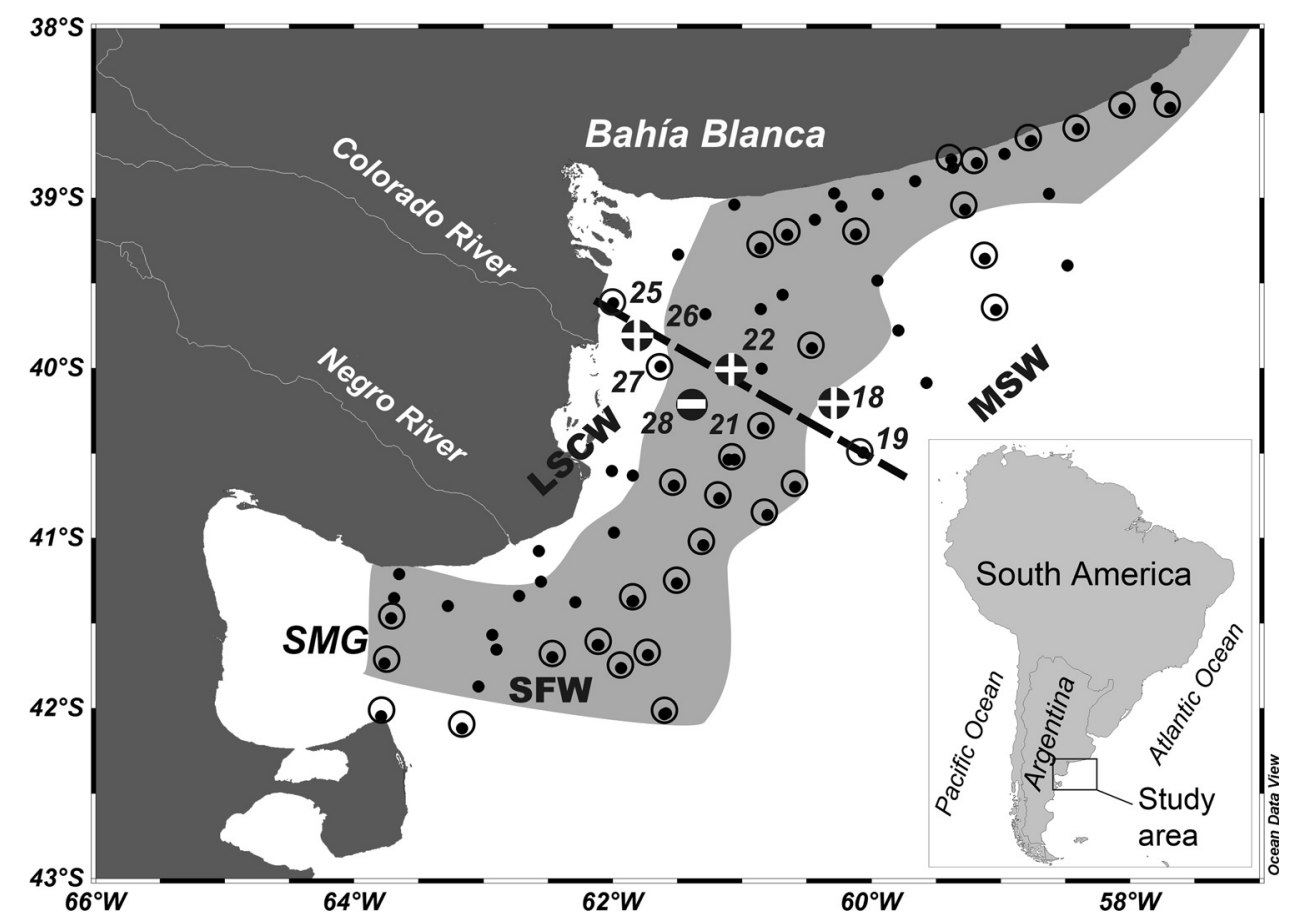

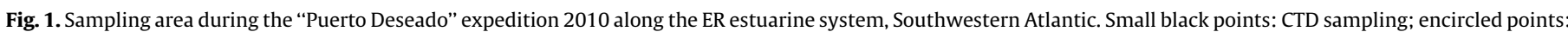

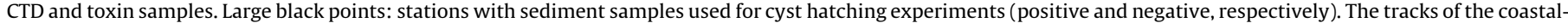

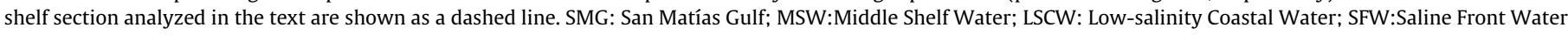
(shaded grey).

distributed from the inner to the outer edge of the ER in a section with depths varying from $20 \mathrm{~m}$ to $60 \mathrm{~m}$ (Fig. 2B).

\subsubsection{Analysis of organic-walled cyst composition}

Aliquots of $10-15 \mathrm{~g}$ of wet sediments were taken for each station and sieved through $150 \mu \mathrm{m}$ and $10-\mu \mathrm{m}$ Nitex screens to eliminate coarse sand, fine silt and clay. One calibrated tablet of Lycopodium clavatum (BATCH $\mathrm{N}^{\circ} 483216$, Lund University) containing 18,583 spores was added to each sample as exotic marker (Stockmarr, 1971) to calculate cyst concentrations in the sediments. The fraction between 10 and $150 \mu \mathrm{m}$ was treated with cold $10 \% \mathrm{HCl}$ ( $15 \mathrm{~min}$ ) to eliminate carbonates and $48 \% \mathrm{HF}$ $(6 \mathrm{~h})$ to dissolve silicates. The remaining residue was sieved and collected on a $10-\mu \mathrm{m}$ mesh and mounted between slide and coverslip in glycerine gel. Permanent slides were stored at the Colección Palinológica, Laboratorio de Palinología (CONICET-UNS), Bahía Blanca, Argentina. Dinocysts were identified and counted using a transmitted-light microscope (Nikon Eclipse 600 serial number $77255)$ at magnifications of $600 \times$ and $1000 \times$. A minimum of 300 dinocysts per sample were counted to determine the concentration of dinocysts per $\mathrm{g}$ of wet sediment and the relative abundance of each species. The nomenclature of the dinocysts followed Fensome et al. (1993), and the names for the motile dinoflagellates have been used whenever possible. Since the goal was to detect potential cysts of Azadinium, the organic fraction was concentrated from an aliquot volume $\left(1 \mathrm{~cm}^{3}\right)$ of wet sediments from stations 18 and 19 following the protocol of Bolch (1997), using a $5 \mu \mathrm{m}$ mesh for sieving instead of the $20 \mu \mathrm{m}$ net originally described. The recovered organic fraction was carefully checked by light microscopy as described above.

\subsubsection{Analysis of phytoplankton samples}

For phytoplankton quantitative estimations of Niskin bottle samples, cells were enumerated with a phase contrast Leica DMIL LED inverted microscope according to the procedures described by Utermöhl (1958). Subsamples of $50 \mathrm{~mL}$ were left to settle for $24 \mathrm{~h}$ in a composite sedimentation chamber. At least 100 cells of the dominant taxa were counted in one or more strips of the chamber or within random fields at $250 \times$ or $400 \times$, depending on their concentration and size. The whole chamber bottom was also scanned to count large and sparse species. Sixteen surface samples were analyzed (stations 11, 15, 16, 18, 19, 21, 22, 23, 24, 26, 28, 30, $32,34,36$ and 41 ).

\subsection{Cyst hatching from sediment samples, cell isolation}

These experiments were initialized in March 2013, two and a half years after sampling the sediments. Approximately $2 \mathrm{~g}$ of wet sediment from each of four stations $(18,22,26$, and 28$)$ were mixed with $20 \mathrm{~mL}$ of filtered seawater and sonicated for $2 \mathrm{~min}(100 \mathrm{~W})$ to dislodge detrital particles. The watery slurry of each sample was distributed in $0.5 \mathrm{~mL}$ portions to a 24 well plate, each well of which had been prefilled with $1.5 \mathrm{~mL}$ of culture medium. Throughout the whole study a natural seawater medium was prepared with sterile-filtered (0.2 $\mu \mathrm{m}$ VacuCap filters, Pall Life Sciences, Dreieich, Germany) Antarctic seawater (salinity: 34, pH adjusted to 8.0) and enriched with $1 / 10$ strength K-medium (Keller et al., 1987) that was slightly modified by omitting the addition of ammonium ions.

Plates were incubated at $15^{\circ} \mathrm{C}$ under a photon flux density of appr. $50 \mu \mathrm{mol} \mathrm{m} \mathrm{m}^{-2} \times \mathrm{s}^{-1}$ on a 16:8 h light:dark photocycle in a controlled environment growth chamber (Model MIR 252, Sanyo Biomedical, Wood Dale, USA). The plates were regularly inspected for the presence of motile cells under a stereomicroscope (Olympus SZH-ILLD; Olympus, Hamburg, Germany) with dark field illumination. Azadinium cells are characterized by their characteristic size and shape and by their conspicuous swimming pattern, i.e. swimming at low speed, interrupted by short, highspeed 'jumps' in various directions (Tillmann et al., 2009; Tillmann et al., 2014b). Cells exhibiting such a characteristic swimming behaviour were isolated using a microcapillary into single wells of 96 well plates each prefilled with $0.3 \mathrm{~mL}$ of culture medium. Only one strain was established from one primary container. In this 


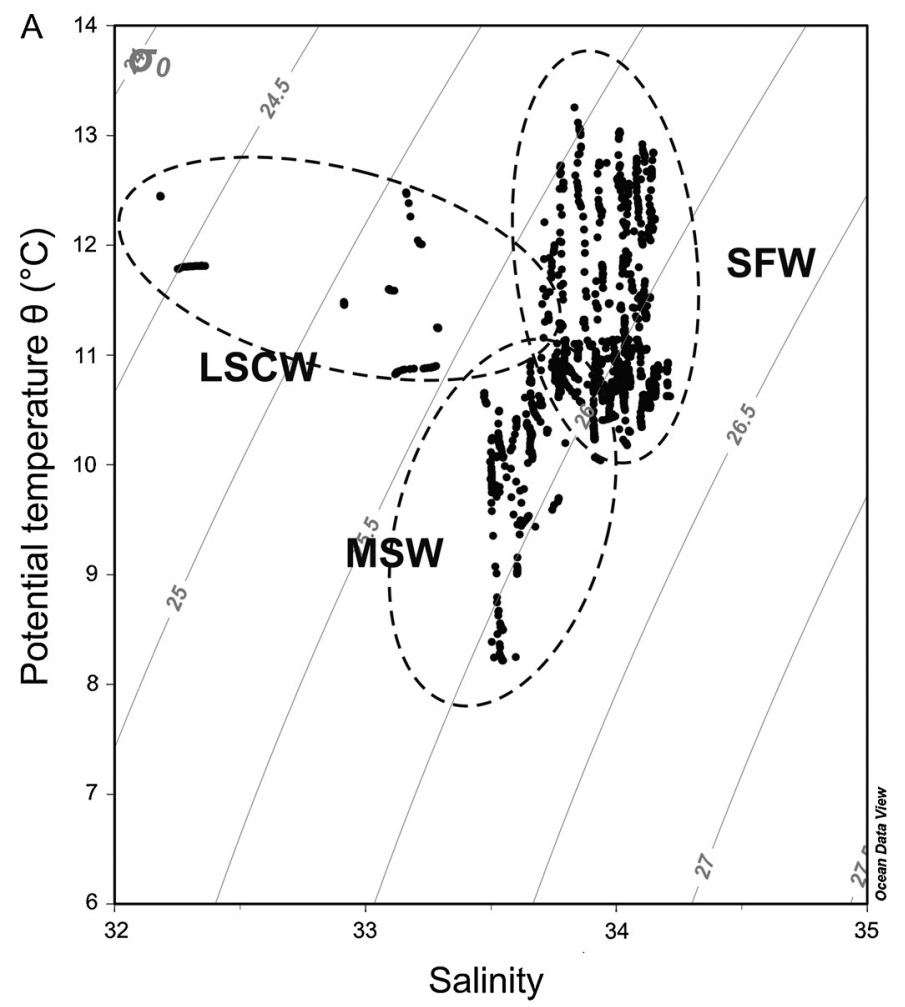

B

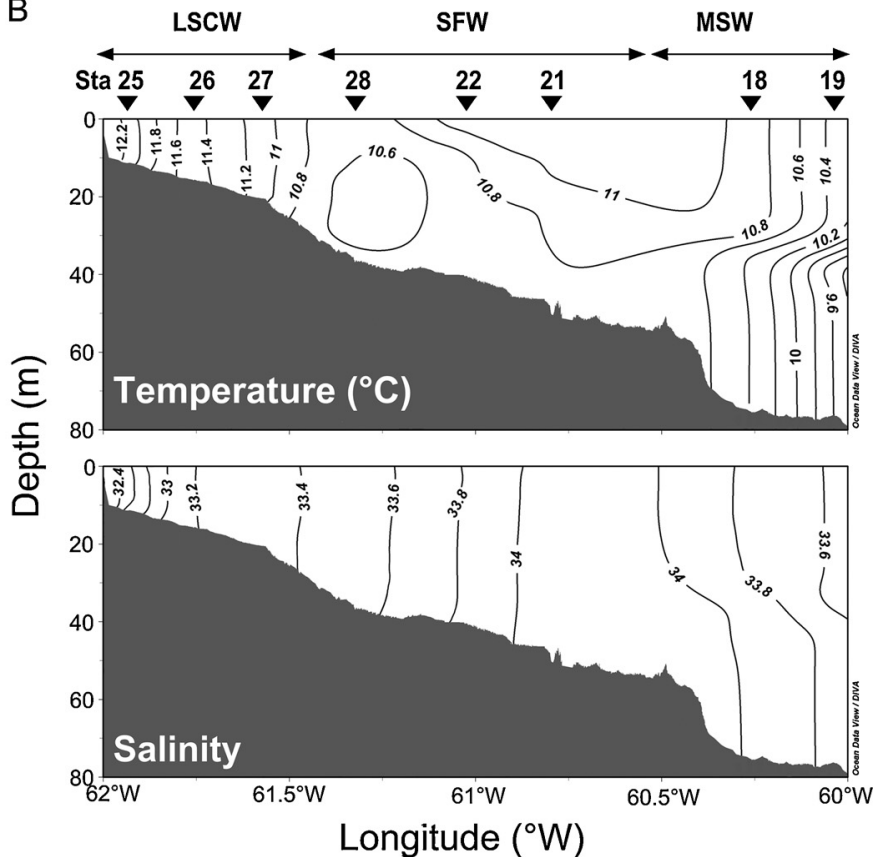

Fig. 2. (A) T-S diagram of CTD casts of the entire expedition showing the different water masses (encircled). Low-salinity Coastal Water (LSCW), Saline Front Water (SFW) and Middle Shelf Water (MSW). (B) Coastal to offshore transect in the ER estuarine system showing temperature and salinity gradient: Low-salinity Coastal Water (LSCW, Sta. 25-27), Saline Front Water (SFW, Sta. 28, 22, 21) and weak stratification outside of the Middle Shelf Water (MSW, Sta. 18, 19).

manner 10 isolates were successfully isolated, 8 of them originating from station 18 (18A1; $18 \mathrm{~B} 2 ; 18 \mathrm{~B} 4 ; 18 \mathrm{C} 3 ; 18 \mathrm{C} 4$; $18 \mathrm{C} 5 ; 18 \mathrm{D} 2 ; 18 \mathrm{D} 4)$ and one isolate each from stations 22 (22 C1) and 26 (26 B5). Established cultures were routinely held at $15^{\circ} \mathrm{C}$ in a temperature controlled culture room at $60 \mu \mathrm{E} \mathrm{m}^{-2} \times \mathrm{s}^{-1}$ and a 16:8 light:dark photocycle.

\subsection{Culture growth, sampling for DNA and toxins}

For toxin analysis, strains were grown in $250 \mathrm{~mL}$ plastic culture flasks at $15^{\circ} \mathrm{C}$ under a photon flux density of $60 \mu \mathrm{mol} \mathrm{m}^{-2} \times \mathrm{s}^{-1}$ on a 16:8 h light:dark photocycle. For each harvest, cell density was determined by settling Lugol-fixed samples and counting $>800$ cells under an inverted microscope. Densely grown strains (ranging from about 10 to $100 \times 10^{4}$ cells $\mathrm{mL}^{-1}$ ) were harvested in four $50 \mathrm{~mL}$ centrifugation tubes. After centrifugation (Eppendorf 5810 R, Hamburg, Germany) at $3220 \times g$ for $10 \mathrm{~min}$, the four pellets were combined in a microtube, again centrifuged (Eppendorf 5415, $16,000 \times \mathrm{g}, 5 \mathrm{~min}$ ), and stored at $-20^{\circ} \mathrm{C}$ until use. Growth and harvest procedures were repeated several times (total volume harvested ranging from $1.2 \mathrm{~L}$ to $1.9 \mathrm{~L}$ for different isolates) to yield a total number of at least $5 \times 10^{7}$ cells per isolate. Total cell number of each isolate was used to calculate the AZA cell quota.

For DNA extraction, each isolate was grown in $65 \mathrm{~mL}$ plastic culture flasks under the standard culture conditions described above. $50 \mathrm{~mL}$ of healthy and growing culture (based on stereomicroscopic inspection of the live culture) were harvested by centrifugation (Eppendorf 5810R, Hamburg, Germany; $3220 \times \mathrm{g}$ for $10 \mathrm{~min}$ ). Each pellet was transferred to a microtube, again centrifuged (Eppendorf 5415, 16,000 $\times \mathrm{g}, 5 \mathrm{~min}$ ), and stored frozen at-80 ${ }^{\circ} \mathrm{C}$ until use.

\subsection{Microscopy}

Observation of live or fixed (formalin: $1 \%$ final concentration; or neutral Lugol-fixed: $1 \%$ final concentration) cells was carried out using an inverted microscope (Axiovert $200 \mathrm{M}$, Zeiss, Germany) and a compound microscope (Axiovert 2, Zeiss, Germany), both equipped with epifluorescence and differential interference contrast optics. Light microscopic examination of the thecal plates was performed on formalin fixed cells ( $1 \%$ final concentration) stained with calcofluor white (Fritz and Triemer, 1985). The shape and location of the nucleus was determined after staining of formalin-fixed cells for $10 \mathrm{~min}$ with 4'-6-diamidino-2-phenylindole (DAPI, $0.1 \mu \mathrm{g} \mathrm{mL}^{-1}$ final concentration). Photographs were taken with a digital camera (Axiocam MRc5, Zeiss, Germany).

Cell length and width were measured at $1000 \times$ microscopic magnification using Zeiss Axiovision software (Zeiss, Germany) and freshly fixed cells (formalin, final concentration 1\%) from dense but healthy and growing cultures (based on stereomicroscopic inspection of the live culture) at late exponential phase. For a selected number of strains, cell size was also analysed at late stationary phase. For SEM, cells were collected by centrifugation (Eppendorf 5810R, Hamburg, Germany, $3220 \times \mathrm{g}$ for $10 \mathrm{~min}$ ) from 2 to $15 \mathrm{~mL}$ of culture, depending on cell density. The supernatant was removed and the cell pellet re-suspended in 60\% ethanol in a $2 \mathrm{~mL}$ microtube for $1 \mathrm{~h}$ at $4{ }^{\circ} \mathrm{C}$ to strip off the outer cell membrane. Subsequently, cells were pelleted by centrifugation (5 min, $16,000 \times g$, Eppendorf centrifuge $5415 \mathrm{R}$ ) and re-suspended in a $60: 40$ mixture of deionized water and seawater for $30 \mathrm{~min}$ at $4{ }^{\circ} \mathrm{C}$. After centrifugation and removal of the diluted seawater supernatant, cells were fixed with formalin ( $2 \%$ final concentration in a 60:40 mixture of deionized water and seawater) and stored at $4{ }^{\circ} \mathrm{C}$ for $3 \mathrm{~h}$. Cells were then collected on polycarbonate filters (Millipore, $25 \mathrm{~mm} \emptyset, 3 \mathrm{~mm}$ pore-size) in a filter funnel where all subsequent washing and dehydration steps were carried out. A total of eight washings ( $2 \mathrm{~mL}$ MilliQ-deionized water each) were followed by a dehydration series in ethanol $(30,50,70,80,95$, $100 \% ; 10$ min each). Filters were dehydrated with hexamethyldisilazane (HMDS), first in 1:1 HMDS:EtOH followed by two times $100 \%$ HMDS, and then stored under gentle vacuum in a desiccator. Finally, filters were mounted on stubs, sputtercoated (Emscope SC500, Ashford, UK) with gold-palladium and viewed under a 
scanning electron microscope (FEI Quanta FEG 200, Eindhoven, Netherlands). Some SEM micrographs were presented on a black background using Adobe Photoshop 6.0 (Adobe Systems, San Jose, USA).

\subsection{Molecular phylogeny}

\subsubsection{DNA extraction and sequencing}

Cell pellets were extracted using the DNeasy extraction kit (Qiagen) following the protocol provided by the manufacturer, with little modifications. Lysis was made using warm lysis buffer $\left(65^{\circ} \mathrm{C}\right)$, cells were transferred to a suspension of glass beads and disrupted and homegenised by reciprocal shaking at maximum speed $\left(6.5 \mathrm{~m} \mathrm{~s}^{-1}\right)$ in a FastPrep instrument (Thermo Savant, Illkirch, France), $4 \mu \mathrm{L}$ of RNAse was added, and elution was made in $50 \mu \mathrm{L}$ of elution buffer. Polymerase chain reaction (PCR) for large subunit ribosomal DNA (LSU rDNA) was performed using primers D1 C (5'-ACCCGCTGAATTTAAGCATA- $\left.3^{\prime}\right)$ and D2R (5'CCTTGGTCCGTGTTTCAAGA-3') (Scholin et al., 1994), and PCR for internal transcribed spacer ribosomal DNA (ITS rDNA) was performed using primers ITSa (5'-CCAAGCTTCTAGATCGTAACAAGG(ACT)TCCGTAGGT- $3^{\prime}$ ) and ITSb (5'-CCTGCAGTCGACA(GT)ATGCTTAA(AG)TTCAGC(AG)GG-3') (Adachi et al., 1996). Genomic DNA was amplified in a $20 \mu \mathrm{L}$ PCR reaction containing $16.3 \mu \mathrm{L}$ of milliQ water, $2.0 \mu \mathrm{L}$ of $10 \times$ HotMaster Taq Buffer (Eppendorf), which included $\mathrm{MgCl}_{2}, 0.2 \mu \mathrm{L}$ of each primer $(10 \mu \mathrm{M}), 0.2 \mu \mathrm{L}$ of dNTP $(10 \mu \mathrm{M}), 0.1 \mu$ l HotMaster Taq polymerase (Eppendorf), and $10 \mathrm{ng}$ of DNA $\mu \mathrm{L}^{-1}$. A Mastercycler Personal Termocycler (Eppendorf) was used for PCR reactions, with PCR reaction conditions for LSU amplification as follows: 2 min at $94{ }^{\circ} \mathrm{C}$, followed by 30 cycles of $30 \mathrm{~s}$ at $94{ }^{\circ} \mathrm{C}, 30 \mathrm{~s}$ at $55^{\circ} \mathrm{C}, 2 \mathrm{~min}$ at $65^{\circ} \mathrm{C}$, and a final extension of $10 \mathrm{~min}$ at $65^{\circ} \mathrm{C}$; and for ITS amplification: $4 \mathrm{~min}$ at $94{ }^{\circ} \mathrm{C}$, followed by 10 cycles of $50 \mathrm{~s}$ at $94{ }^{\circ} \mathrm{C}, 40 \mathrm{~s}$ at $58^{\circ} \mathrm{C}, 1 \mathrm{~min}$ at $70^{\circ} \mathrm{C}$, and then 30 cycles of $45 \mathrm{~s}$ at $94{ }^{\circ} \mathrm{C}, 45 \mathrm{~s}$ at $50{ }^{\circ} \mathrm{C}, 1 \mathrm{~min}$ at $70^{\circ} \mathrm{C}$, and a final extension of $5 \mathrm{~min}$ at $70^{\circ} \mathrm{C}$.

The PCR products were purified with a MinElute PCR purification kit (Qiagen) and sequenced using an ABI $3130 \mathrm{XL}$ capillary sequencer (Applied Biosystems). The sequencing reaction contained $1 \mu \mathrm{L}$ of purified PCR product, $1.5 \mu \mathrm{L}$ of BigDye Buffer (Life Technologies), $0.3 \mu \mathrm{L}$ of BigDye, $1 \mu \mathrm{L}$ of PCR primer (forward or reverse) and $7.2 \mu \mathrm{L}$ of milliQ water. Conditions for sequencing reactions were as follows: $1 \mathrm{~min}$ at $96^{\circ} \mathrm{C}$, followed by 25 cycles of $10 \mathrm{~s}$ at $96^{\circ} \mathrm{C}, 5 \mathrm{~s}$ at $50^{\circ} \mathrm{C}$, and $4 \mathrm{~min}$ at $60^{\circ} \mathrm{C}$. Sequencing products were purified with Agencourt CleanSEQ Dye Terminator Removal (Beckman Coulter) and sequenced in both directions.

Sequences were examined and checked for accuracy of basecalling using the ABI Sequencing Analysis protocol. Sequences were assembled using the AlignX module from Vector NTI software (Life Technologies).

\subsubsection{Phylogenetic analysis}

The ITS and LSU rDNA sequences from 41 Azadinium spp. were gathered from GeneBank (release 203 from august 2014). Together with the 10 ITS and LSU rDNA sequences from the Argentinean Azadinium this gave a total of 51 Azadinium ITS plus LSU sequences (Table S01, Supplementary Material). Amphidoma languida was used as outgroup. These sequences were concatenated resulting in a total of 52 Amphidomataceae sequences, with an average length of $1301 \mathrm{pb}$.

Phylogenetic analysis was performed using maximum likelihood (ML) and Bayesian inference methods, using MEGA 6 (Tamura et al., 2013) and MrBayes v3.2.5 (Huelsenbeck and Ronquist, 2001), respectively. For this, sequences were aligned using Muscle (Edgar, 2004) with 32 iterations followed by manual inspection. The alignment file ( ${ }^{*}$.mas, ${ }^{*}$.nexus) is available upon request. For ML, aligned sequences were subjected to Model Selection to find the best nucleotide substitution model, and to phylogeny reconstruction with the Kimura 2-parameter model for nucleotide substitutions (Kimura, 1980) with five discrete Gamma categories and 500 bootstrap replications. For Bayesian analysis, the best nucleotide substitution model was found using MrModeltest (https://github.com/nylander/MrModeltest2), and Bayesian inference was performed with the $G T R+I+G$ model for nucleotide substitutions (Tavaré, 1986) and 10,000 replications. Statistical support values (ML-BS: ML-bootstrap support and B-PP: Bayesian posterior probability) were included on the resulting best scoring ML-tree.

Genetic pairwise similarities between both ITS and LSU sequences from Azadinium poporum were calculated after global alignments using the ClustalW using the AlignX module from Vector NTI software (Life Technologies).

Sequences were deposited in NCBI under accession numbers KT382999 to KT383018.

\subsection{Chemical analysis of azaspiracids}

\subsubsection{Field samples}

Polycarbonate filters with $20 \mu \mathrm{m}$ pre-screened samples from the Niskin bottles were repeatedly rinsed with $1 \mathrm{~mL}$ of methanol until the filters were completely decolourized. The methanolic extracts were transferred to a spin-filter $(0.45 \mu \mathrm{m}$ pore-size, Millipore Ultrafree, Eschborn, Germany) and centrifuged for $30 \mathrm{~s}$ at $800 \times g$, followed by transfer to autosampler vials.

\subsubsection{Cell cultures}

Cell pellets were extracted with $500 \mu \mathrm{L}$ of methanol by ultrasonication (Sonoplus HD 2070, Bandelin, Berlin, Germany; $70 \mathrm{~s} / 70$ cycles $/ 10 \%$ power). Extracts were then centrifuged (Eppendorf $5415 \mathrm{R}$, Hamburg, Germany) at $16,100 \times g$ at $4{ }^{\circ} \mathrm{C}$ for $10 \mathrm{~min}$. Each supernatant was transferred to a $0.45-\mu \mathrm{m}$ pore-size spin-filter (Millipore Ultrafree, Eschborn, Germany) and centrifuged for $30 \mathrm{~s}$ at $800 \times \mathrm{g}$, and the resulting filtrate being transferred into an LC autosampler for LC-MS/MS analysis.

\subsubsection{Single reaction monitoring (SRM) measurements}

Water was deionized and purified (Milli-Q, Millipore, Eschborn, Germany) to $18 \mathrm{M} \Omega \mathrm{cm}^{-1}$ or better quality. Formic acid (90\%, p.a.), acetic acid (p.a.) and ammonium formate (p.a.) were purchased from Merck (Darmstadt, Germany). The solvents, methanol and acetonitrile, were high performance liquid chromatography (HPLC) grade (Merck, Darmstadt, Germany).

Mass spectral experiments were performed to survey for a wide array of AZA and were done with an analytical system consisting of an AB-SCIEX-4000 Q Trap, triple quadrupole mass spectrometer equipped with a TurboSpray interface coupled to an Agilent model 1100 LC. The LC equipment included a solvent reservoir, in-line degasser (G1379A), binary pump (G1311A), refrigerated autosampler (G1329A/G1330B), and temperature-controlled column oven (G1316A).

Separation of AZA ( $5 \mu \mathrm{L}$ sample injection volume) was performed by reverse-phase chromatography on a $C 8$ phase. The analytical column $(50 \mathrm{~mm} \times 2 \mathrm{~mm})$ was packed with $3 \mu \mathrm{m}$ Hypersil BDS $120 \AA$ (Phenomenex, Aschaffenburg, Germany) and maintained at $20^{\circ} \mathrm{C}$. The flow rate was $0.2 \mathrm{~mL} \mathrm{~min}^{-1}$, and gradient elution was performed with two eluents, where eluent $A$ was water and B was acetonitrile/water $(95: 5, \mathrm{v} / \mathrm{v})$, both containing $2.0 \mathrm{mM}$ ammonium formate and $50 \mathrm{mM}$ formic acid. Initial conditions were 8 min column equilibration with $30 \%$ B, followed by a linear gradient to $100 \% \mathrm{~B}$ in $8 \mathrm{~min}$ and isocratic elution until $18 \mathrm{~min}$ with $100 \% \mathrm{~B}$ then returning to initial conditions until $21 \mathrm{~min}$ (total run time: $29 \mathrm{~min}$ ). 
Table 1

Mass transitions $m / z$ (Q1 > Q3 mass) and their respective AZA.

\begin{tabular}{lll}
\hline Mass transition & Toxin & $\begin{array}{l}\text { Collision energy } \\
(\mathrm{CE})[\mathrm{V}]\end{array}$ \\
\hline $716>698$ & AZA-33 & 40 \\
$816>798$ & AZA-39 & 40 \\
$816>348$ & AZA-39 & 70 \\
$828>658$ & AZA-3 & 70 \\
$828>810$ & AZA-3 & 40 \\
$830>812$ & AZA-38 & 40 \\
$830>348$ & AZA-38 & 70 \\
$842>672$ & AZA-1 & 70 \\
$842>824$ & AZA-1, AZA-41 & 40 \\
$844>826$ & AZA-4, AZA-5 & 40 \\
$846>828$ & AZA-37 & 40 \\
$856>672$ & AZA-2 & 70 \\
$856>838$ & AZA-2 & 40 \\
$858>840$ & AZA-7, AZA-8, AZA-9, AZA-10, AZA-36 & 40 \\
$868>362$ & Undescribed & 70 \\
$870>852$ & Me-AZA-2 & 40 \\
$872>854$ & AZA-11, AZA-12 & 40 \\
$936>918$ & AZA-2 phosphate & 40 \\
\hline
\end{tabular}

Azaspiracid profiles were determined in one period (0-18 min) with curtain gas: 10 psi, CAD: medium, ion spray voltage: $5500 \mathrm{~V}$, temperature: ambient, nebulizer gas: 10 psi, auxiliary gas: off, interface heater: on, declustering potential: $100 \mathrm{~V}$, entrance potential: $10 \mathrm{~V}$, exit potential: $30 \mathrm{~V}$ ). SRM experiments were carried out in positive ion mode by selecting the transitions shown in Table 1. In field samples, AZA were measured against an external standard solution of AZA-1 (certified reference material (CRM) programme of the IMB-NRC, Halifax, Canada). Azadinium poporum cultures were calibrated against an external standard solution of AZA-2 (CRM) and expressed as AZA-2 equivalents.

\subsubsection{Precursor ion experiments}

Precursors of the fragments $m / z 348$ and $m / z 362$ were scanned in the positive ion mode from $\mathrm{m} / \mathrm{z} 400$ to 950 under the following conditions: curtain gas: 10 psi, CAD: medium, ion spray voltage: $5500 \mathrm{~V}$, temperature: ambient, nebulizer gas: 10 psi, auxiliary gas: off, interface heater: on, declustering potential: $100 \mathrm{~V}$, entrance potential: $10 \mathrm{~V}$, collision energy: $70 \mathrm{~V}$, exit potential: $12 \mathrm{~V}$.

\subsubsection{Product ion spectra}

Product ion spectra were recorded in the Enhanced Product Ion (EPI) mode in the mass range from $\mathrm{m} / \mathrm{z} 150$ to 940 . Positive ionization and unit resolution mode were used. The following parameters were applied: curtain gas: 10 psi, CAD: medium, ion spray voltage: $5500 \mathrm{~V}$, temperature: ambient, nebulizer gas: $10 \mathrm{psi}$, auxiliary gas: off, interface heater: on, declustering potential: $100 \mathrm{~V}$, collision energy spread: $0,10 \mathrm{~V}$, collision energy: $70 \mathrm{~V}$.

\subsubsection{FTICR-MS measurements}

Mass spectra were acquired with a Solarix XR Fourier transform ion cyclotron resonance mass spectrometer (FTICR-MS; Bruker Daltonik GmbH, Bremen, Germany) equipped with a $12 \mathrm{~T}$ refrigerated actively shielded superconducting magnet (Bruker Biospin, Wissembourg, France), a Dual ion source and a Paracell ${ }^{\mathrm{TM}}$ analyzer cell. The samples were ionized using electrospray in positive ion mode. Sample solutions were continuously infused using a syringe at a flow rate of $120 \mu \mathrm{L} \mathrm{h}^{-1}$. The detection mass range was set to $m / z 150-3000$. Ion accumulation time was set to $0.1 \mathrm{~s}$. Data sets were acquired with $4 \mathrm{MW}$ data points resulting in a resolving power of 450,000 at $\mathrm{m} / \mathrm{z} 400$. Spectra were zero-filled to process size of $8 \mathrm{M}$ data points before sine apodization and Fourier transformation.

Mass spectra were calibrated with arginine cluster using a linear calibration. A $10 \mu \mathrm{g} \mathrm{ml}^{-1}$ solution of arginine in $50 \%$ methanol was used to generate the arginine clusters. For MS/MS experiments accumulation time was up to several seconds, the isolation window was $0.5 \mathrm{Da}$ and collision energy was set to $30 \mathrm{eV}$.

\section{Results}

\subsection{Field sampling}

\subsubsection{Hydrographical conditions}

The coastal-shelf waters transition is illustrated by a T-S diagram (Fig. 2A) of all CTD stations showing coastal waters of minimum salinity (LSCW), a near-shore salinity maximum (SFW) and the middle shelf water (MSW) occupying the central portion of the shelf. For the area where sediment samples for cyst hatching experiments were collected, data sets of selected stations (see dashed line, Fig. 1) were chosen to generate temperature and salinity sections (Fig. 2B). The oceanographic data showed zones with different vertical structures: (i) a zone close to the coast with depths of $12-23 \mathrm{~m}$, low salinity $(32.17<S<33.28)$ and high temperature $\left(11.25<T\left({ }^{\circ} \mathrm{C}\right)<12.45\right)$; (ii) a middle zone with depth of $30-37 \mathrm{~m}$, higher salinity $(33.46<S<34.05)$ and lower temperature $\left(10.56<T\left({ }^{\circ} \mathrm{C}\right)<11.11\right)$, and (iii) an external zone weakly stratified with depths around $46-68 \mathrm{~m}$, intermediate salinities $(33.56<S<33.98)$ and lower temperatures $(9.44<T$ $\left.\left({ }^{\circ} \mathrm{C}\right)<10.94\right)$, typical for middle shelf waters (Fig. 2B).

\subsubsection{Plankton composition}

Phytoplankton abundance along the study area ranged from $9.3 \times 10^{3}$ to $824.1 \times 10^{3}$ cells L $^{-1} \quad(n=16)$. Unidentified tiny phytoflagellates $(<5 \mu \mathrm{m})$ dominated phytoplankton assemblages at most stations ( 11 of 16 ), accounting for an average of $65.8 \%$ of total cells. Diatoms predominated at 4 stations, reaching a maximum of about $120 \times 10^{3}$ cells L $^{-1}$ in northern and offshore waters, where relatively large-size species like Cerataulina pelagica, Meuniera membranacea and Eucampia antarctica were commonly observed. In addition, dinoflagellates predominated only at one station located to the south, in which small $(<15 \mu \mathrm{m})$ naked dinoflagellates reached about $20 \times 10^{3}$ cells L $^{-1}$.

In particular, phytoplankton abundance in samples corresponding to the four stations selected for cyst hatching was relatively low, ranging from $9.3 \times 10^{3}$ to $45.9 \times 10^{3}$ cells $\mathrm{L}^{-1}$. Phytoplankton assemblages were dominated by unidentified tiny phytoflagellates $(<5 \mu \mathrm{m})$, which accounted for $62-96 \%$ of total cells. Diatoms $(x=9.2 \%)$, dinoflagellates $(x=7.7 \%)$, cryptophytes $(x=0.8 \%)$ and prasinophytes $(x-=0.4 \%)$ were found in lower concentrations. Diatoms were particularly abundant at station 26, where they reached $12.1 \times 10^{3}$ cells $\mathrm{L}^{-1}$. Asterionellopsis glacialis, Rhizosolenia pungens, Thalassiosira spp. (15-25 $\mu \mathrm{m})$ and Fallacia sp. were the most common taxa observed at this station. Dinoflagellate abundance ranged from $0.9 \times 10^{3}$ to $3.0 \times 10^{3}$ cells $\mathrm{L}^{-1}$ and was mainly dominated by small $(<15 \mu \mathrm{m})$ naked dinoflagellates. Ceratium fusus, C. tripos, Gyrodinium cf. fusus, G. cf. glaciale, Polykrikos sp., Prorocentrum cf. minimum, Scripsiella spp. and Protoperidium spp. were also observed in low concentrations. No Azadinium-like cells (based on size and shape) were observed in any of the analysed samples.

\subsubsection{Dinoflagellate cysts}

The dinoflagellate cyst assemblages recovered from sediment samples were taxon rich, and twenty-five types were identified. Photosynthetic taxa were dominated by Protoceratium reticulatum, accompanied by Gonyaulax cf. spinifera (cyst name: Spiniferites ramosus, Spiniferites cf. pachydermus and Spiniferites mirabilis) and Gonyaulax cf. scrippsae (cyst name: Spiniferites bulloideus). Cysts of heterotrophic species reached high proportions at stations 28, 26 and 22 (Fig. 3), and were mainly represented by Protoperidinium 


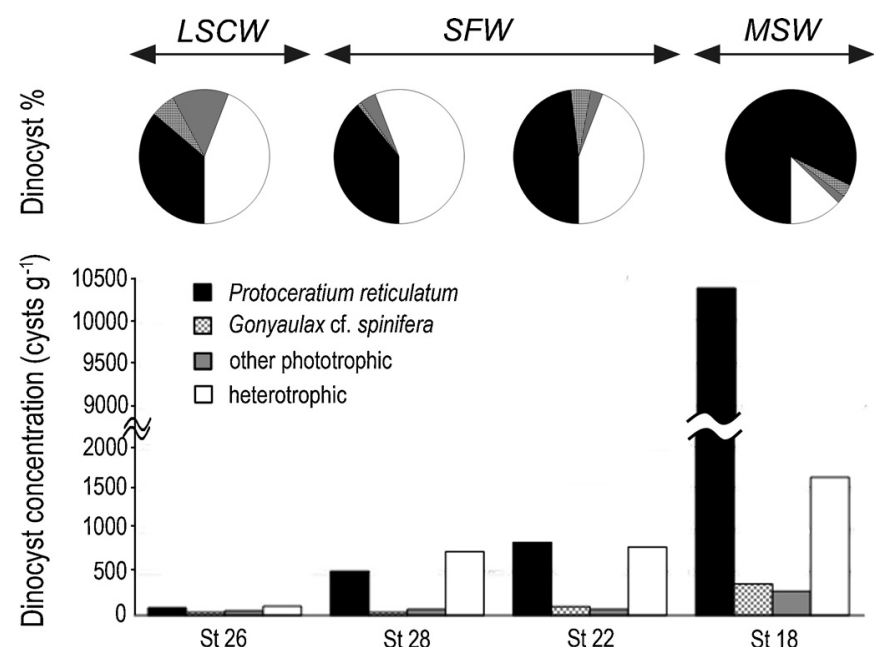

Fig. 3. Relative abundances (\%) and concentrations (cysts $\mathrm{g}^{-1}$ ) of cysts of phototrophic and heterotrophic dinoflagellates in the surface sediments of Stations 26, 28, 22 and 18.

spp. (Protoperidinium conicum, P. claudicans, P. oblongum, P. avellanum, $P$. leonis, $P$. conicoides, $P$. obtusum, $P$. stellatum, $P$. subinerme, P. nudum, Archaeperidinium minutum), Polykrikos kofoidii/P. schwartzii, Diplopsalioideae, and other morphotypes including in the genus Echinidinium (brown spiny dinocyst taxa of unknown biological affinity). A marked increase in the proportion of cysts of photosynthetic species was registered for station 18 , which was primarily caused by an increase of Protoceratium reticulatum cysts. Total dinoflagellate cyst concentrations per gram

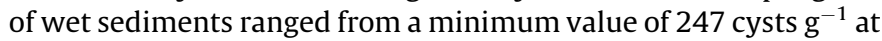
station 26 to $12,480 \times 10^{3}$ cysts $\mathrm{g}^{-1}$ at station 18 (Fig. 3 ) with an increase from the inner low salinity coastal waters (LSCW) toward the outer part of the ER estuarine system. The highest values were observed in the hydrographic frontal zone between the Saline Front Waters (SFW) and Middle Shelf Waters (MSW). Despite a careful and high resolution inspection of the smallest size organic fraction from sediments of stations 18 and 19, potential cysts of Azadinium could not be unambiguously detected or identified.

\subsubsection{Azaspiracids}

No AZA were detected in any of the field samples in the planktonic size fraction between 3 and $20 \mu \mathrm{m}$. The limit of detection $(\mathrm{S} / \mathrm{N}=3)$ was determined as $2.3 \mathrm{pg}$ on column for AZA-1.

\subsection{Azadinium poporum cultures}

\subsubsection{Morphology, light- and electron microscopy}

A number of small dinoflagellate cells (as identified at low magnification by shape and swimming patterns) were observed in wells with sediment samples after about $1 \frac{1 / 2}{2}$ weeks of incubation. Among those, Azadinium-like cells as defined by their conspicuous swimming pattern (see accompanying video in Tillmann et al., 2009) were isolated as single cells, and from these 10 clonal cultures of Azadinium were obtained. Light- and electron microscopy of all isolates confirmed that they all were identical in terms of morphology and that they all represented the species Azadinium poporum. The following micrographs and descriptions are mainly based on strain 26B5, unless otherwise specified in the text and/or figure legend.

Concordant with previous descriptions of the species, the Argentinean Azadinium poporum were ovoid and had a broad descending cingulum and an episome, which was higher than the hyposome and terminated in a conspicuous apical pore complex (APC) (Fig. 4A-C). Pyrenoid(s) with a starch sheath (visible as a ring-like structure) were always present (Fig. 4B and C). The most common number of pyrenoids per cell was two, one located in the epi- and hyposome, respectively (Fig. 4C). Size (Fig. 4D) and number of pyrenoids (Fig. 4E) was variable, but it was generally difficult to unambiguously identify the quantity of pyrenoids for all specimens. The number of cells with three clearly visible pyrenoids within 200 cells examined for each isolate was between 1 and 7. The presence of 4 pyrenoids could not unambiguously be determined, but it could not be excluded that more cells had multiple ( $>2$ ) but hidden and/or masked pyrenoids. A presumably single chloroplast was parietally arranged, lobed and retiform in the episome, and extending with lateral connections into the hyposome (Fig. 4F).

Cell size and shape was variable, ranging from small and more rounded to large elongated and bullet-shaped (Fig. 4G and H). Cell sizes of the isolates are listed in Table 2. Cells of healthy growing cultures in late exponential phase were quite variable in size ranging from $10.6 \mu \mathrm{m}$ to $17.5 \mu \mathrm{m}$ in cell length and ranging from 7.8 to $13.0 \mu \mathrm{m}$ in cell width. Although ANOVA indicated statistically significant differences in cell length and width among isolates (cell length: $F=17.8, p<0.05$; cell width: $F=8.9, p<0.05$ ), mean size of all isolates were very close to the overall mean length of $14.1 \mu \mathrm{m}$ and width of $10.2 \mu \mathrm{m}$. For a selected number of isolates cell size was also measured for stationary phase (Table 2, Fig. 5). These cells were significantly larger (Fig. 5), mainly due to an increase in cell length, which ranged up to $19.8 \mu \mathrm{m}$. This caused the length/width ratio of stationary cells to be significantly larger as well. For all isolates there was very conspicuous variability in shape of the hyposome, which ranged from rounded (Fig. 4I) to more triangular (Fig. $4 \mathrm{~J}$ and $\mathrm{K}$ ) to irregularly pointed (Fig. $4 \mathrm{~L}$ ); it sometimes appeared as a small horn-like posterior protuberance (Fig. 4M). The interphase nucleus located in the cingulum region was oval (Fig. 4N and O). In dividing cells the nucleus was distinctly elongated, stretching almost the whole cell length with nuclear division taking place along the longitudinal axis (Fig. 4P and Q). Cytokinesis by oblique fission was observed in motile cells and was of the desmoschisis type, i.e. the parental theca was shared between the two sister cells (Fig. 4R). In stationary phase, the size of the chloroplast was drastically reduced, and cells sometimes had a number of grains of presumably reserve material both in the epiand hyposome (Fig. 4S). This differed from pyrenoids in the absence of a clear starch sheath covering them and in that they were occasionally of plate-like structure in the hyposome (Fig. 4T).

Plate pattern with the Kofoidean plate formula of Po, cp, X, 4', $3 a, 6^{\prime \prime}, 6 \mathrm{C}, 5 \mathrm{~S}, 6^{\prime \prime \prime}, 2^{\prime \prime \prime \prime}$, plate size and arrangement, as well as presence and location of the ventral pore (Fig. 6) were in agreement with previous descriptions of the type material for Azadinium poporum (Tillmann et al., 2011). A series of 4 apical plates, with the right lateral Plate $4^{\prime}$ being larger than the left lateral Plate $2^{\prime}$, surrounded the rounded apical pore plate and were followed by a series of six precingular plates (Fig. 6D). Three symmetrically arranged intercalary plates were located dorsally with the smaller median Plate 2a in contact with four other plates (quadra configuration) (Fig. 6D). The hypotheca consisted of six postcingular plates and two unequally sized antapical plates (Fig. 6E). In contrast to all previous description of $A$. poporum, all isolates of the Argentinean A. poporum were characterised by a distinct field of pores located on the second antapical plate, typically close to the dorsal area where Plate $2^{\prime \prime \prime \prime}$ abuts Plates $4^{\prime \prime \prime}$ and $5^{\prime \prime \prime}$ (Fig. 6E-G). In this area, 10 to 20 pores with a diameter of about $0.1 \mu \mathrm{m}$ were typically more or less regularly arranged in short rows. Normally, a small number (ca. 3-6) of pores was additionally present and scattered nearby adjacent to the ordered area (Fig. 6F and G). The round to ellipsoid apical pore was covered by a cover plate and connected to the first apical plate by a finger-like protrusion as a three-dimensional outgrowth of the 

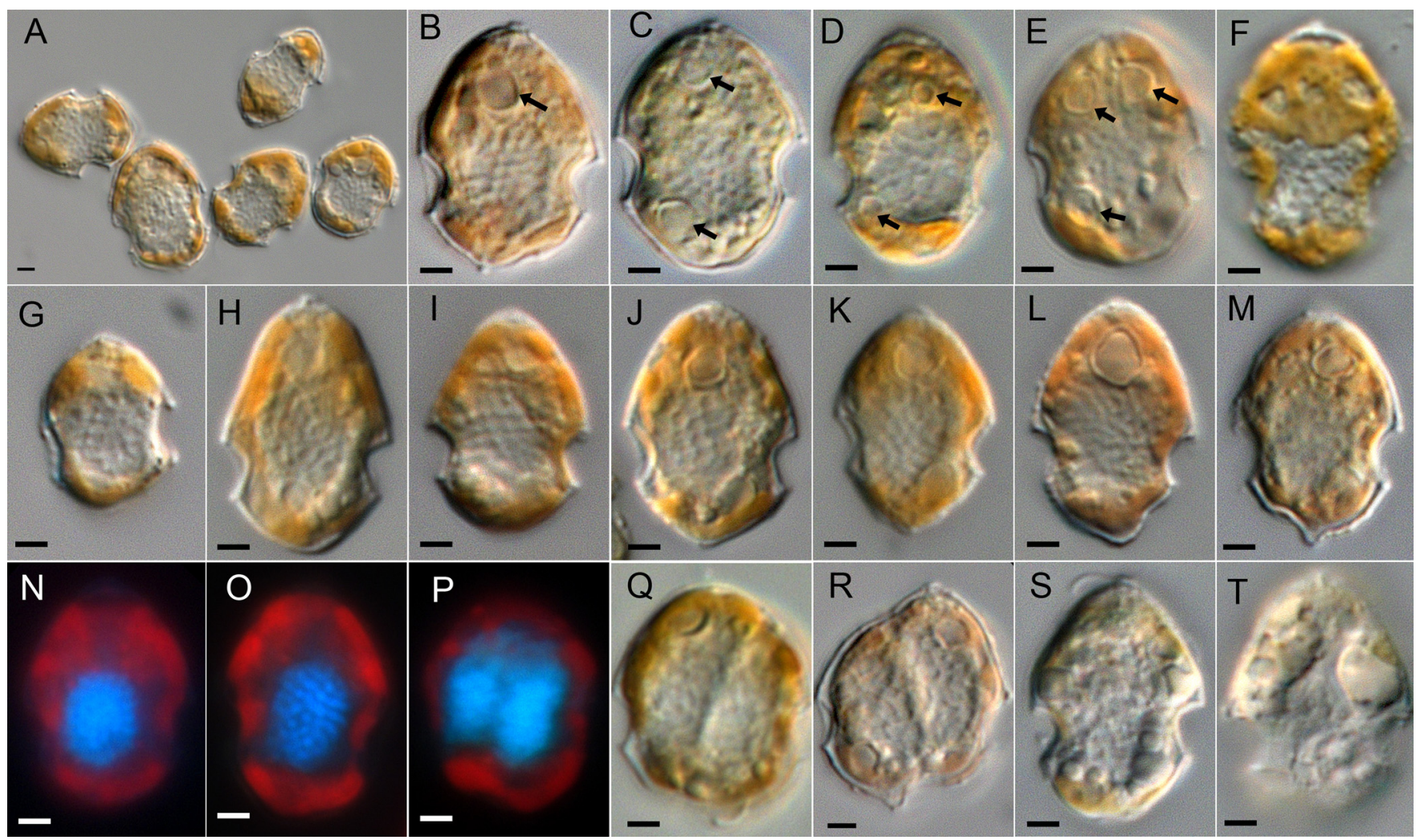

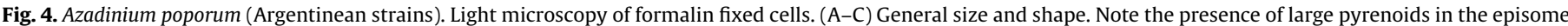

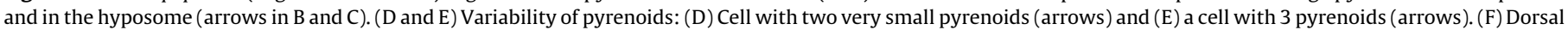

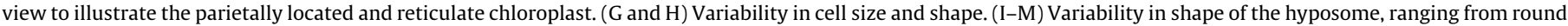

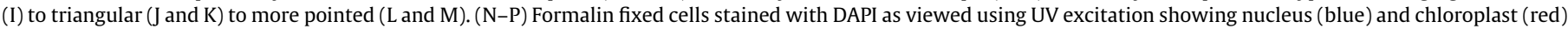

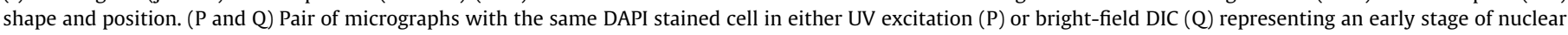

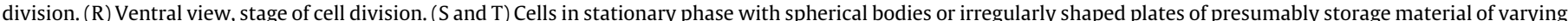

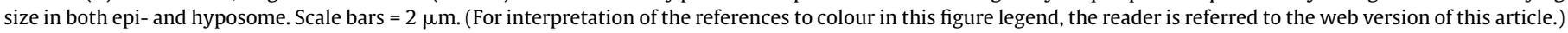

small X-plate, which in internal view was visible as a small and oval plate (Fig. $6 \mathrm{H}$ and I). A conspicuous ventral pore was located at the left lateral side of the pore plate (Fig. $6 \mathrm{H}$ and I). The six cingular plates were of comparable size. Also present were five sulcal plates, with a three dimensional structure and the median sulcal plate Ss running across from the first cingular plate $\mathrm{C} 1$ to the last cingular plate C6 as typical for the family Amphidomataceae (Fig. 6J and K).

The cultured strains exhibited some variability in terms of shape of plates, and this variability was found within all isolates, with no obvious difference between them. Fig. 7A-D shows different shapes of the first apical Plate $1^{\prime}$, which was variable in plate width and whose posterior part ranged from relatively broad (Fig. 7B) to narrow and with a tapered end (Fig. 7C). In a few cases the first apical plate was without direct contact to the anterior sulcal plate Sa (Fig. 7D). The shape of the median dorsal apical Plate $3^{\prime}$ was also variable, with Plate $3^{\prime}$ being symmetric on either longitudinal and lateral axis (Fig. 7E) or being more elongated and thus symmetrical on the longitudinal axis only (Fig. 7F). As also evident by LM, the shape of the hypotheca and the larger antapical Plate $2^{\prime \prime \prime \prime \prime}$ was very variable, ranging from round (Fig. 7G) to more triangular outline (Fig. $7 \mathrm{H}$ ) with Plate $2^{\prime \prime \prime \prime}$ forming a more or less pointed end (Fig. 7I and $\mathrm{J}$ ) and sometimes even forming a distinct protuberance (Fig. $7 \mathrm{~K}$ and $\mathrm{L}$ ). The pore (Fig. 7M-P) plate typically was ovoid or horseshoe-shaped but could also be almost circular (Fig. 7M) or distinctly elongated in outline (Fig. 7P).

In addition to variability in shape of single plates, a number of deviations from the typical plate pattern were observed in the Artgentinean isolates. Exemples are shown in the supplementary material (Suppl. Fig. S1). Variations in plate pattern primarily consisted of additional sutures between the epithecal plates (Fig. S1A-I), although variation in number of hypothecal plates was also observed (Fig. S1J and K). The position of the ventral pore was consistent among hundreds of inspected cells, but as a rare exception the pore was displaced posteriorly in one cell (Fig. S1L).

\subsubsection{Phylogeny}

ML and Bayesian inferred phylogenetic trees from ITS+LSU sequences from 52 Amphidomataceae taxa ( 51 from Azadinium spp. plus Amphidoma languida), yielded almost identical topologies. The best scoring ML tree $(-\ln =6655.34)$ is shown in Fig. 8; most nodes had high statistical support. Within the Azadinium clade, the ten species described, i.e. Azadinium poporum, A. dalianense, A. spinosum, A. obesum, A. trinitatum, A. cuneatum, A. polongum, A. dexteroporum, A. caudatum and $A$. concinnum, were clearly distinguishable and monophyletic, although not all branches had a high statistical support. In agreement with previous reports, $A$. concinnum appeared as the most ancestral Azadinium species, and A. dalianense AZCH02, as the sister species of $A$. poporum in a well-supported clade (ML-BS: 75 and B-PP: 1). The concatenated ITS+LSU rDNA sequences of the ten Argentinean strains isolated in this study (Fig. 8, names in bold) fell unequivocally inside the A. poporum clade (ML-BS: 99, B-PP: 1), and were most similar to $A$. poporum isolates from the East China Sea, South China Sea, Bohai Sea and strain HJ-2011 from Shiwha Bay, Korea. Specifically, all the Argentinean strains were located with Chinese A. poporum strains belonging to ribotype $C$ in a wellsupported clade (ML-BS: 99, B-PP: 1). Statistical values of branches inside ribotype $C$ did not support differentiation between Argentinean and Chinese strains. 
Table 2

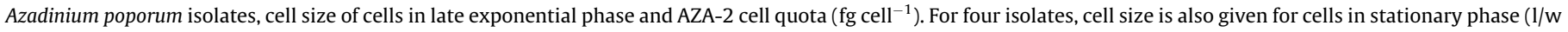
ratio= length/width ratio; stat. = stationary phase; n.d. = not determined).

\begin{tabular}{|c|c|c|c|c|c|}
\hline Strain & $\begin{array}{l}\text { Length }[\mu \mathrm{m}] \\
\text { Mean } \pm 1 \mathrm{std} \\
\text { Min-max }\end{array}$ & $\begin{array}{l}\text { Width }[\mu \mathrm{m}] \\
\text { Mean } \pm 1 \mathrm{std} \\
\text { Min-max }\end{array}$ & $\begin{array}{l}\text { l/w ratio } \\
\text { Mean } \pm 1 \text { std } \\
\text { Min-max }\end{array}$ & $N$ & AZA-2 cell quota [ fg cell $\left.^{-1}\right]$ \\
\hline $18 \mathrm{~A} 1$ & $\begin{array}{l}\mathbf{1 4 . 2} \pm 1.2 \\
11.6-16.8\end{array}$ & $\begin{array}{l}\mathbf{1 0 . 5} \pm 0.9 \\
8.3-12.1\end{array}$ & $\begin{array}{l}\mathbf{1 . 3 6} \pm 0.06 \\
01.21-1.52\end{array}$ & 108 & 2.9 \\
\hline 18 B2 & $\begin{array}{l}\mathbf{1 4 . 0} \pm 1.2 \\
11.2-17.1\end{array}$ & $\begin{array}{l}\mathbf{1 0 . 2} \pm 0.8 \\
8.5-12.3\end{array}$ & $\begin{array}{l}\mathbf{1 . 3 8} \pm 0.06 \\
1.22-1.60\end{array}$ & 136 & 5.1 \\
\hline $18 \mathrm{~B} 4$ & $\begin{array}{l}14.2 \pm 1.0 \\
11.9-16.4\end{array}$ & $\begin{array}{l}\mathbf{1 0 . 2} \pm 0.8 \\
8.3-12.1\end{array}$ & $\begin{array}{l}\mathbf{1 . 3 9} \pm 0.06 \\
1.20-1.58\end{array}$ & 111 & 5.4 \\
\hline $18 \mathrm{C} 3$ & $\begin{array}{l}\mathbf{1 4 . 5} \pm 1.0 \\
11.3-17.3\end{array}$ & $\begin{array}{l}\mathbf{1 0 . 3} \pm 0.7 \\
8.5-12.1\end{array}$ & $\begin{array}{l}\mathbf{1 . 4 0} \pm 0.07 \\
1.23-1.58\end{array}$ & 110 & 2.0 \\
\hline $18 \mathrm{C} 4$ & $\begin{array}{l}\mathbf{1 3 . 4} \pm 1.0 \\
11.1-15.9\end{array}$ & $\begin{array}{l}\mathbf{1 0 . 0} \pm 0.8 \\
8.2-11.8\end{array}$ & $\begin{array}{l}\mathbf{1 . 3 4} \pm 0.06 \\
1.22-1.53\end{array}$ & 135 & 1.6 \\
\hline 18 C5 & $\begin{array}{l}\mathbf{1 4 . 0} \pm 1.2 \\
11.6-16.9\end{array}$ & $\begin{array}{l}\mathbf{1 0 . 1} \pm 0.8 \\
8.2-12.1\end{array}$ & $\begin{array}{l}\mathbf{1 . 4 0} \pm 0.06 \\
1.24-1.57\end{array}$ & 124 & 6.9 \\
\hline 18 D2 & $\begin{array}{l}\mathbf{1 3 . 4} \pm 1.0 \\
10.6-16.3\end{array}$ & $\begin{array}{l}\mathbf{9 . 9} \pm 0.8 \\
7.8-12.2\end{array}$ & $\begin{array}{l}\mathbf{1 . 3 5} \pm 0.05 \\
1.23-1.50\end{array}$ & 130 & 2.4 \\
\hline 18 D4 & $\begin{array}{l}\mathbf{1 4 . 4} \pm 1.1 \\
11.3-16.7\end{array}$ & $\begin{array}{l}\mathbf{1 0 . 4} \pm 0.8 \\
8.4-12.9\end{array}$ & $\begin{array}{l}\mathbf{1 . 3 9} \pm 0.06 \\
1.26-1.52\end{array}$ & 110 & 2.3 \\
\hline $22 \mathrm{C} 1$ & $\begin{array}{l}\mathbf{1 4 . 4} \pm 1.1 \\
12.0-17.5\end{array}$ & $\begin{array}{l}\mathbf{1 0 . 5} \pm 0.8 \\
8.8-13.0\end{array}$ & $\begin{array}{l}\mathbf{1 . 3 7} \pm 0.06 \\
1.23-1.56\end{array}$ & 134 & 4.7 \\
\hline 26 B5 & $\begin{array}{l}\mathbf{1 4 . 0} \pm 1.2 \\
11.5-16.7\end{array}$ & $\begin{array}{l}\mathbf{1 0 . 3} \pm 0.9 \\
8.3-12.7\end{array}$ & $\begin{array}{l}\mathbf{1 . 3 7} \pm 0.08 \\
1.21-1.57\end{array}$ & 120 & 2.5 \\
\hline 18 C3 stat. & $\begin{array}{l}\mathbf{1 5 . 2} \pm 1.2 \\
11.8-17.5\end{array}$ & $\begin{array}{l}\mathbf{1 0 . 8} \pm 1.0 \\
8.0-12.8\end{array}$ & $\begin{array}{l}\mathbf{1 . 4 1} \pm 0.08 \\
1.24-1.65\end{array}$ & 106 & n.d. \\
\hline 18 C4 stat. & $\begin{array}{l}\mathbf{1 5 . 9} \pm 1.6 \\
12.2-19.8\end{array}$ & $\begin{array}{l}\mathbf{1 1 . 6} \pm 1.3 \\
8.5-14.9\end{array}$ & $\begin{array}{l}1.37 \pm 0.07 \\
1.14-1.60\end{array}$ & 132 & n.d. \\
\hline 22 C1 stat. & $\begin{array}{l}\mathbf{1 5 . 1} \pm 1.3 \\
12.5-18.1\end{array}$ & $\begin{array}{l}\mathbf{1 0 . 7} \pm 0.9 \\
8.6-12.6\end{array}$ & $\begin{array}{l}\mathbf{1 . 4 2} \pm 0.07 \\
1.26-1.58\end{array}$ & 117 & n.d. \\
\hline 26 B5 stat. & $\begin{array}{l}\mathbf{1 5 . 0} \pm 1.4 \\
12.1-18.7\end{array}$ & $\begin{array}{l}\mathbf{1 0 . 3} \pm 1.0 \\
8.5-13.3\end{array}$ & $\begin{array}{l}\mathbf{1 . 4 5} \pm 0.08 \\
1.30-1.62\end{array}$ & 96 & n.d. \\
\hline
\end{tabular}

Genetic similarities between Azadinium poporum ITS and LSU sequences independently confirmed the structure of the ITS+LSU ML-tree. Ribotype A strains (comprised of the European isolates) showed a $100 \%$ correspondence at their ITS and LSU sequences, ribotype B strains (comprised by some Chinese and Korean strains) showed a $98.8 \%$ correspondens with 8 variable positions at their ITS sequences and $98 \%$ correspondence with 13 variable positions at their LSU sequences, and ribotype C strains (comprised of Chinese and Argentinean strains) showed a 99.7\% correspondence with 2 variable positions at their ITS and LSU sequences. Argentinean $A$. poporum strains alone were $99.7 \%$ similar in their sequenced ITS and LSU rDNA fragments, with the same two variable positions as the

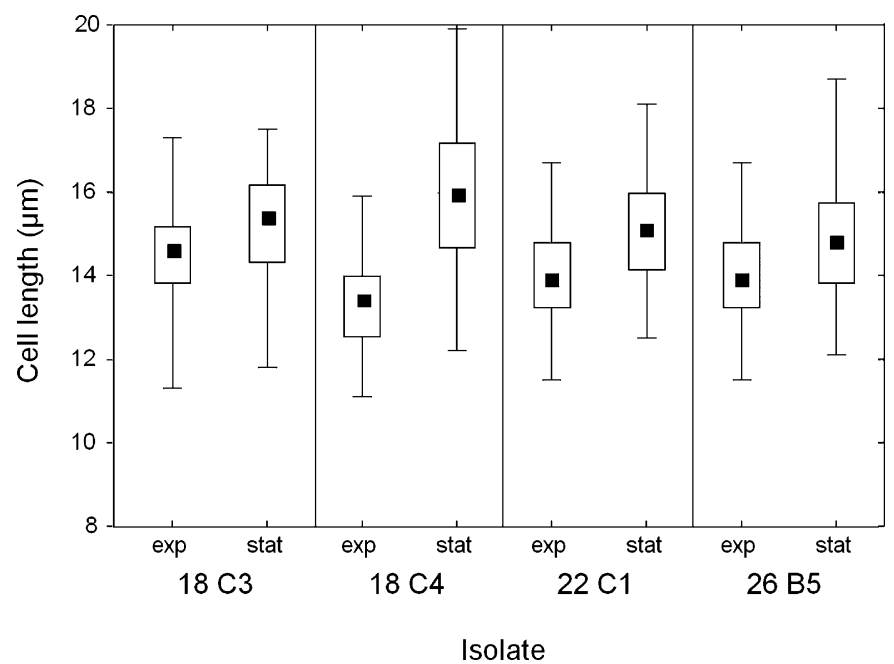

Fig. 5. Cell length of four Argentinean A. poporum isolates in both exponential (exp.) and stationary (stat.) phase of growth. Box-Whisker plots with black squares representing the median, white boxes representing the upper and lower quartiles, and lines representing the range. rest of the ribotype $C$ strains in each fragment analyzed. These slight differences separated all strains from ribotype $C$ in two mixed groups containing both Chinese and Argentinean $A$. poporum strains, indicating no genetic differentiation of their ITS and LSU sequences in terms of geographical origin. Table 3 shows pairwise comparisons of partial ITS and LSU sequences of representative strains from each ribotype of $A$. poporum.

\subsubsection{Azaspiracids}

Azaspiracids were detected in Azadinium poporum cultures established from sediments. All isolates displayed the same AZA profile, consisting of a peak of the ion trace $\mathrm{m} / \mathrm{z} 856>838$ at $12.4 \mathrm{~min}$ and a minor peak of the ion trace $\mathrm{m} / \mathrm{z} 870>852$ at $14.1 \mathrm{~min}$. The peak at $12.4 \mathrm{~min}$ was unambiguously attributed to AZA-2 by retention time comparison of the samples with a standard solution of AZA-2 and by comparison of collision induced dissociation (CID) spectra. We had previously identified the peak at 14.1 min as AZA-2 methyl ester, by derivatization of AZA-2 with diazomethane (unpublished results). Precursor scans of $\mathrm{m} / \mathrm{z}$ 362 showed a third peak at $11.5 \mathrm{~min}$ with the mass of $\mathrm{m} / \mathrm{z}$ 936. The CID spectrum of $m / z 936$ showed some typical fragments of AZA, such as the group 2-4 fragments (Krock et al., 2012), but not the typical cleavage of several water molecules from the pseudo molecular ion (Fig. 9). Determination of the sum formula of this compound by FTICR-HRMS resulted in $\mathrm{C}_{48} \mathrm{H}_{74} \mathrm{NO}_{15} \mathrm{P}$, which is consistent with AZA-2 phosphate (Table 4). The A. poporum AZA profiles were dominated by AZA-2 (>95\%), and AZA-2 methyl ester and compound $m / z 936$ accounted for $1 \%$ and 3.5\%, respectively. AZA-2 cell quotas ranged from $1.6 \mathrm{pg} \mathrm{cell}^{-1}$ in strain $18 \mathrm{C} 4$ to $6.9 \mathrm{pg} \mathrm{cell}^{-1}$ in strain $18 \mathrm{C} 5$ (Table 2).

\section{Discussion}

Azadinium poporum was initially described from the North Sea (Tillmann et al., 2011) but has subsequently been identified to 

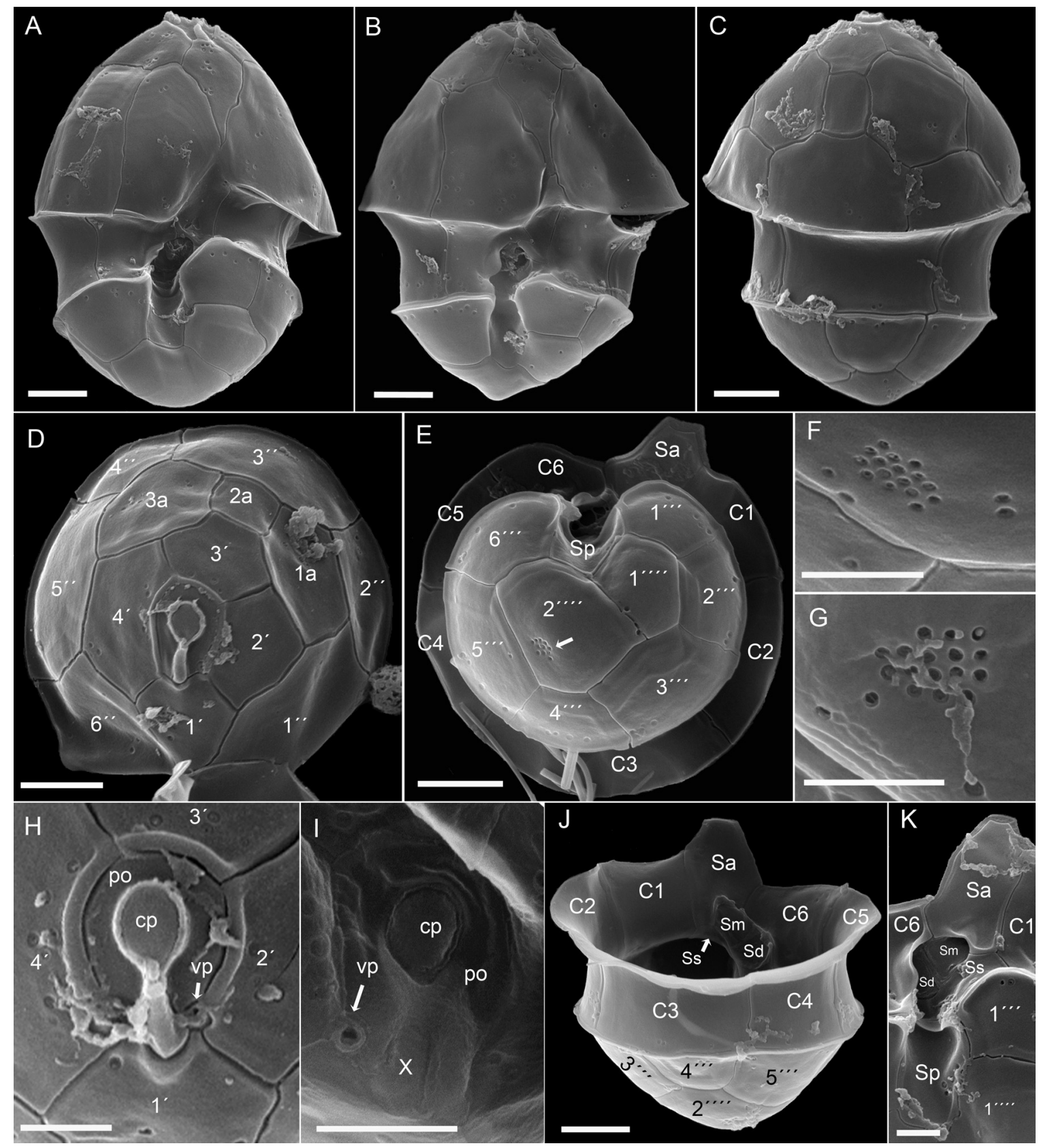

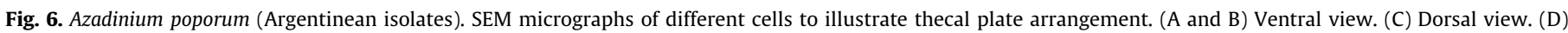
Epitheca in apical view. (E) Hypotheca in antapical view. Note the field of pores on the $2^{\prime \prime \prime \prime \prime}$ plate (white arrow). (F and G) Detailed view of the field of pores on Plate $2^{\prime \prime \prime \prime}$. (H and I) Apical pore complex (APC) in external (H) and internal (I) view. $\mathrm{po}=$ pore plate, $\mathrm{cp}=$ cover plate, $\mathrm{vp}=$ ventral pore, $\mathrm{X}=\mathrm{X}$-plate. (J) Dorsal/apical view of the hypotheca showing the series of cingular plates (C1-C6) with an interior view of the sulcal plates. (K) Details of the sulcal plate arrangement. (Sa: anterior sulcal plate; Sp: posterior sulcal plate; Ss: left sulcal plate; Sm: median sulcal plate; Sd: right sulcal plate). Scale bars $=2 \mu \mathrm{m}$ (A-E, J) or $=1 \mu \mathrm{m}(\mathrm{F}-\mathrm{I}$ and $\mathrm{K})$.

occur in the Asian Pacific in both Korean (Potvin et al., 2012) and Chinese coastal waters (Gu et al., 2013). With the first record of $A$. poporum from Argentina, an important range extension of the species to the south Atlantic is presented, thus confirming that the genus Azadinium has a rather widespread global distribution (Tillmann et al., 2014c).

\subsection{Morphology}

Both morphology and phylogeny indicate that all new isolates indeed represent Azadinium poporum. At the light microscopy level, general size and shape as well as the presence of multiple pyrenoids with a starch sheath (visible as a ring-like structure) are in accordance with the type material of $A$. poporum. With respect to thecal plates there are a number of morphological key characters separating species in the genus of Azadinium, i.e., the presence of an antapical spine, and/or the number, size, and arrangement of epithecal plates, and/or the location of a ventral pore (Tillmann et al., 2014a; Tillmann et al., 2014c). The South Atlantic bloom species of Azadinium described before as A. cf. spinosum (Akselman and Negri, 2012) clearly had an antapical spine and therefore, even in the absence of complementary morphological, molecular and toxinological data for that taxon, undoubtedly is a species different from the isolates described here. For all the new Argentinean isolates it is particularly the distinct position of the ventral pore located at the junction of the pore plate and the first two apical 


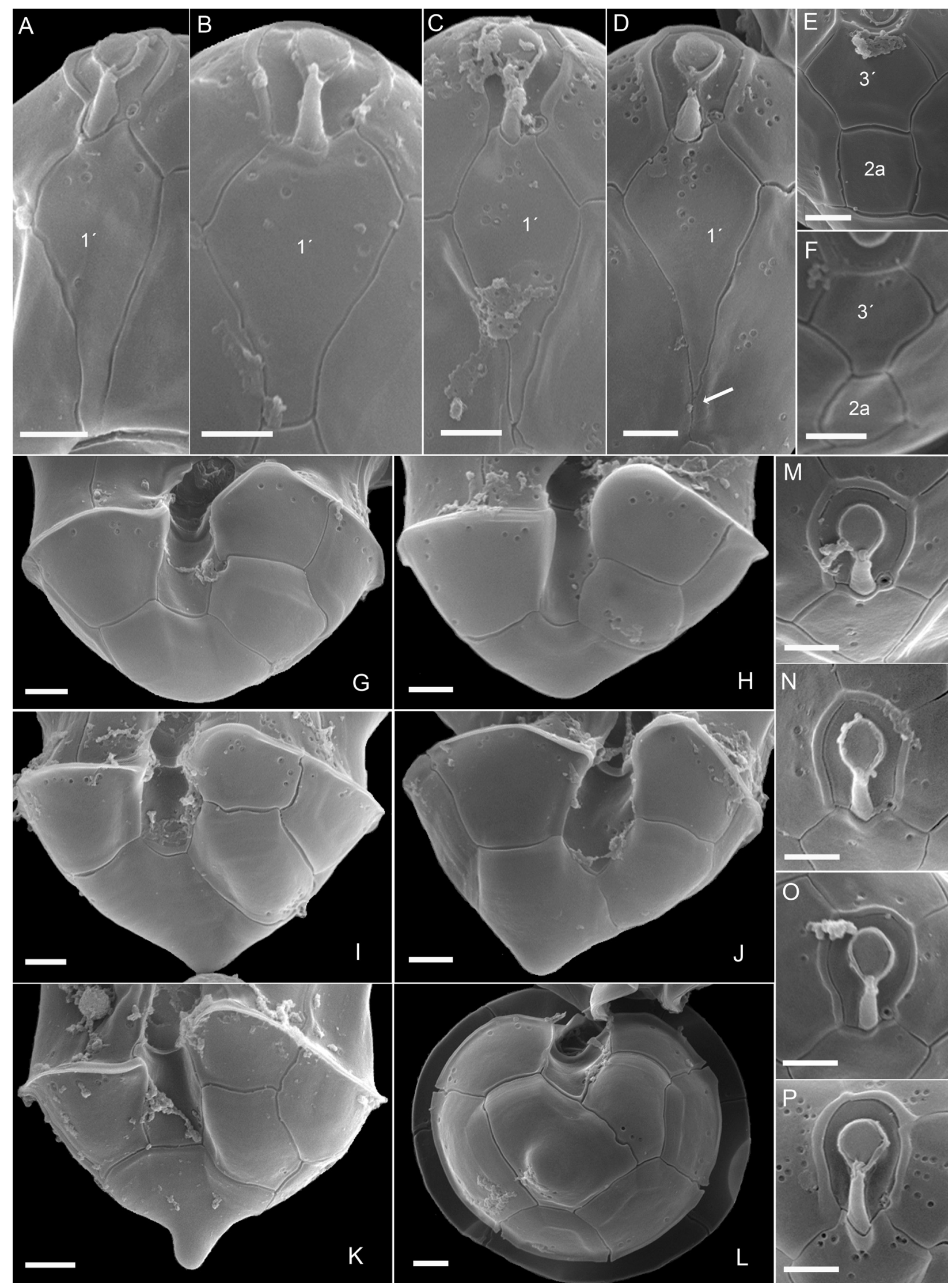

Fig. 7. Azadinium poporum (Argentinean isolates): SEM micrographs of different cells to illustrate variability in shape of certain thecal plates. (A-D) Variability in shape of the first apical Plate $1^{\prime}$. Note the loss of contact (white arrow) of the tapered end of $1^{\prime}$ to the anterior sulcal plate in (D). (E and F) Variability in shape of the median dorsal apical Plate $3^{\prime}$. (G-L) Variability in shape of the hypotheca and the most posteriourly located antapical Plate $2^{\prime \prime \prime \prime}$ in ventral (G-K) or antapical (L) view. (M-P) Variability in shape of the pore plate of the APC. Scale bars $=1 \mu \mathrm{m}$. 


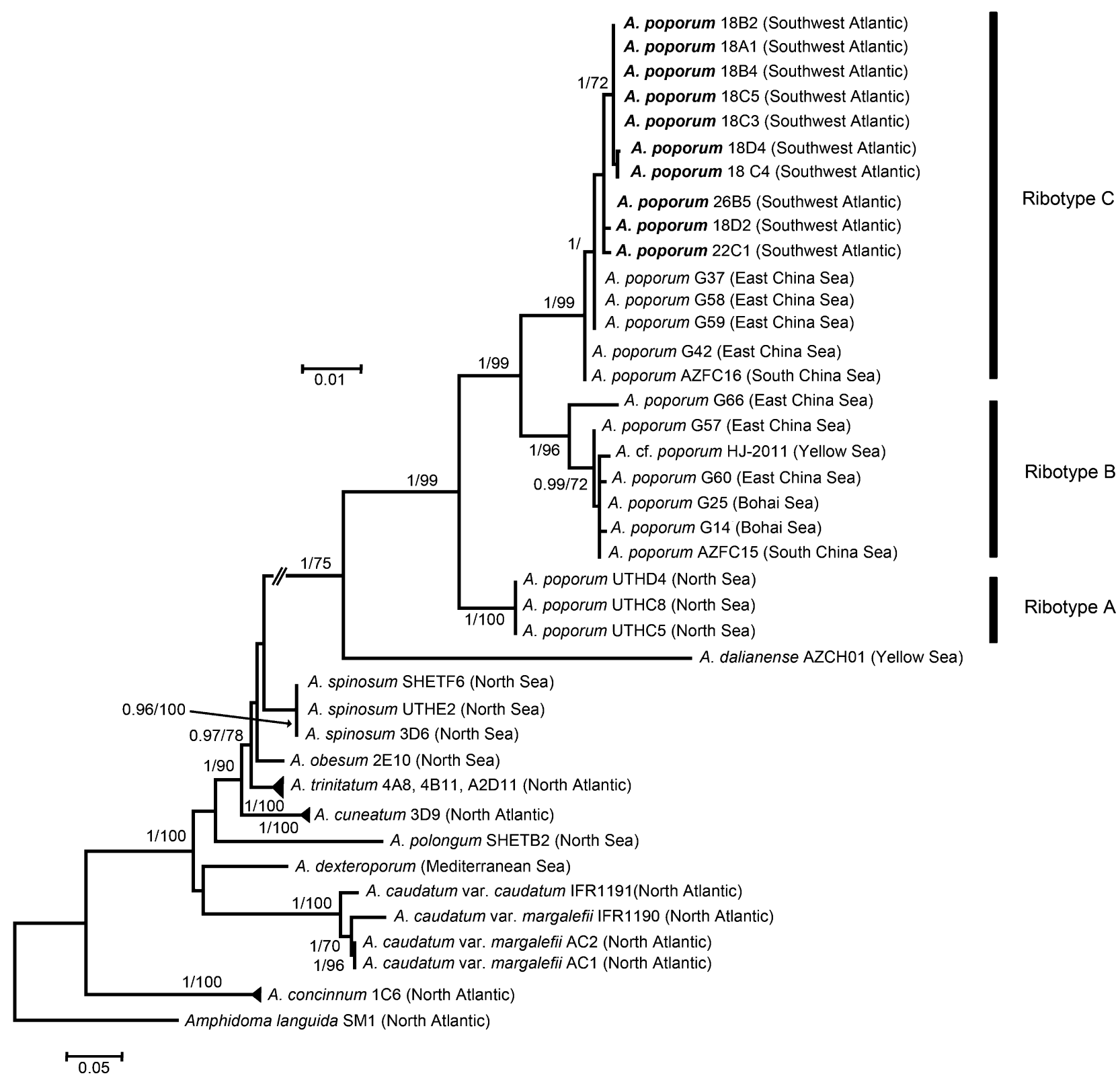

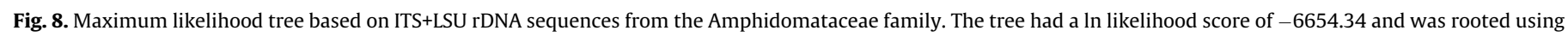

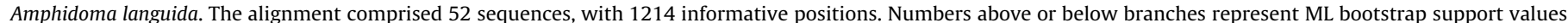

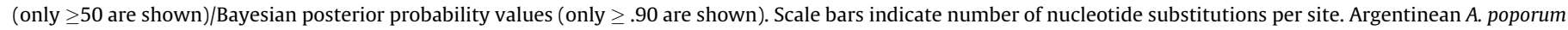
strains characterized in this study are shown in bold.

plates, in combination with the number of apical and intercalary plates and the absence of a spine, that identified them as $A$. poporum. Azadinium dalianense has a similar position of the ventral pore but has a reduced number of both apical plates ( 3 in $A$. dalianense versus 4 in $A$. poporum) and intercalary plates ( 2 in $A$. dalianense versus 3 in A. poporum) (Luo et al., 2013). A. trinitatum also has a superficially similar position of the ventral pore but has an antapical spine, and here the position of the ventral pore is slightly displaced posterior compared to A. poporum (Tillmann et al., 2014a). Compared to the type material of $A$. poporum, cells of the Argentinean isolates, however, exhibited a slightly larger variability in size (length: 11-18 $\mu \mathrm{m}$, width $8-13 \mu \mathrm{m}$ ) when compared to the cell size given in the species description (length: 11-16 $\mu \mathrm{m}$, width: 8-12 $\mu \mathrm{m}$ ) (Tillmann et al., 2011), with cells in

Table 3

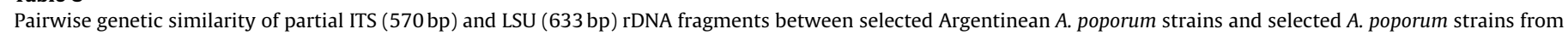
each ribotype and sub-group, and number of variable positions in each gene fragment (in parenthesis).

\begin{tabular}{|c|c|c|c|c|c|c|c|c|}
\hline & \multirow{2}{*}{\multicolumn{2}{|c|}{$\begin{array}{l}\text { Ribotype A } \\
\text { A. poporum UTHC5 }\end{array}$}} & \multirow{2}{*}{\multicolumn{2}{|c|}{$\begin{array}{l}\text { Ribotype B } \\
\text { A. poporum G25 }\end{array}$}} & \multicolumn{4}{|l|}{ Ribotype C } \\
\hline & & & & & \multicolumn{2}{|c|}{ A. poporum G58 } & \multicolumn{2}{|c|}{ A. poporum G42 } \\
\hline & ITS & LSU & ITS & LSU & ITS & LSU & ITS & LSU \\
\hline A. poporum $18 \mathrm{~A} 1$ & $97.5 \%(14)$ & $97.4 \%(16)$ & $98.1 \%(12)$ & $97.7 \%(16)$ & $99.5 \%(3)$ & $99.7 \%(2)$ & $99.5 \%(3)$ & $100 \%(0)$ \\
\hline A. poporum $26 \mathrm{~B} 5$ & $97.4 \%(16)$ & $96.4 \%(25)$ & $98 \%(13)$ & $97.8 \%(16)$ & $99.4 \%(4)$ & $100 \%(0)$ & $99.7 \%(2)$ & $99.7 \%(2)$ \\
\hline
\end{tabular}




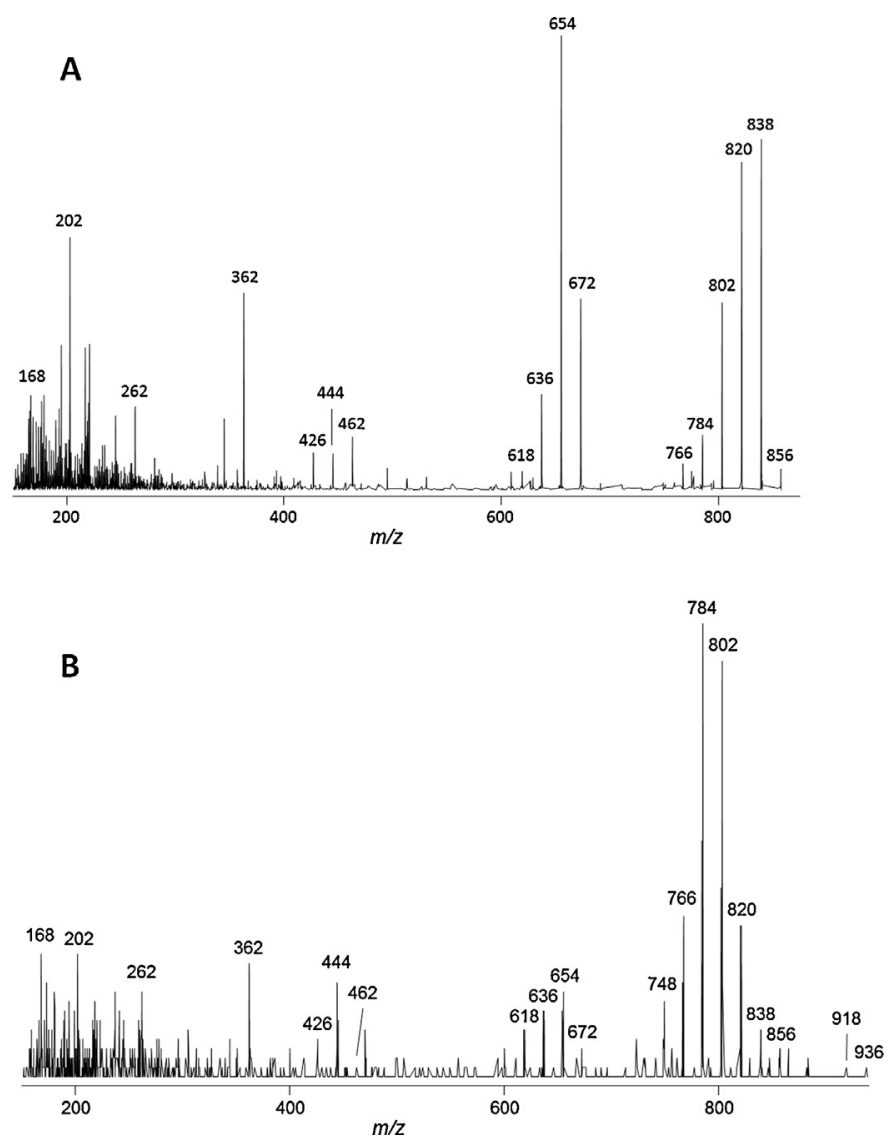

Fig. 9. Collision induced dissociation CID spectra of AZA-2 (A) and AZA-2 phosphate (B).

stationary phase being up to $20 \mu \mathrm{m}$ in length with a shape more slender than commonly described for $A$. poporum.

Although a slightly irregular shape of the hypotheca was also visible in some cells of the Korean (Potvin et al., 2012) and Chinese (Gu et al., 2013) isolates of Azadinium poporum, the large variability of the shape of the hypotheca observed here was striking. The hypotheca was at times pointed or even ended with a horn-like extension and thus superficially resembled the horn-like extension of $A$. caudatum or the pointed antapex of Heterocapsa triquetra. Furthermore, an elongated and/or pointed hypotheca is a common characteristic for most of the early described species of the genus Amphidoma (Schiller, 1937). However, for the Argentinean isolates, such a pointed or rarely horn-like elongated epitheca, although observed within all isolates, was not present in all cells and thus is not a stable morphological trait.

The first available strain of Azadinium poporum outside of Europe, isolated from Shiwha Bay, off South Korea, was initially described as " $A$. cf. poporum" based on a slight but discernible

Table 4

Exact masses of $[\mathrm{M}+\mathrm{H}]^{+}$ions and characteristic group fragments of AZA-2 and AZA-2 phosphate.

\begin{tabular}{lllllll}
\hline & AZA-2 & & & \multicolumn{2}{l}{$\mathrm{H}_{2} \mathrm{PO}_{3}$-AZA-2 } & \\
\cline { 2 - 3 } & AZA-2 & Composition & & Observed & Composition & \pm ppm \\
\hline Group 1 & 856 & $\mathrm{C}_{48} \mathrm{H}_{74} \mathrm{NO}_{12}$ & & 936.48816 & $\mathrm{C}_{48} \mathrm{H}_{75} \mathrm{NO}_{15} \mathrm{P}$ & 1.4 \\
Group 2 & 672 & $\mathrm{C}_{38} \mathrm{H}_{58} \mathrm{NO}_{9}$ & & 672.41105 & $\mathrm{C}_{38} \mathrm{H}_{58} \mathrm{NO}_{9}$ & 0.7 \\
Group 3 & 462 & $\mathrm{C}_{27} \mathrm{H}_{44} \mathrm{NO}_{5}$ & & 462.32138 & $\mathrm{C}_{27} \mathrm{H}_{44} \mathrm{NO}_{5}$ & 0.0 \\
Group 4 & 362 & $\mathrm{C}_{22} \mathrm{H}_{36} \mathrm{NO}_{3}$ & & 362.26892 & $\mathrm{C}_{22} \mathrm{H}_{36} \mathrm{NO}_{3}$ & 0.1 \\
Group 5 & 262 & $\mathrm{C}_{16} \mathrm{H}_{24} \mathrm{NO}_{2}$ & & 262.18007 & $\mathrm{C}_{16} \mathrm{H}_{24} \mathrm{NO}_{2}$ & 0.3 \\
Group 6 & 168 & $\mathrm{C}_{10} \mathrm{H}_{18} \mathrm{NO}$ & & 168.13822 & $\mathrm{C}_{10} \mathrm{H}_{18} \mathrm{NO}$ & 0.4 \\
\hline
\end{tabular}

Note that there is no consistent fragment group numbering in the literature. morphological difference between this isolate and the type material from the North Sea. Potvin et al. (2012) noted that the $3^{\prime}$ plate is usually symmetrical on the AP and lateral axes for the Korean strain, whereas it had been depicted as symmetrical on the AP axis only for the European type material of A. poporum (Potvin et al., 2012, their Fig. 27). However, by analysing a number of Chinese strains of $A$. poporum, Gu et al. (2013) showed that the shape of Plate $3^{\prime}$ can be variable among cells of a single strain ranging from being wide and symmetrical to narrow and symmetrical only in lateral view. The same variability in shape of the $3^{\prime}$ plate was obvious in clonal cultures of the Argentinean isolates. Other plates such as the first apical plate also showed a larger variability in shape; a narrow elongated posterior part of this plate present for some cells had been described as characteristic for A. obesum (Tillmann et al., 2010).

The most conspicuous morphological detail not observed and/ or described before for Azadinium poporum was the presence of a structured field of pores on the second apical plate. The occasional presence of small pores on Plate $2^{\prime \prime \prime}$ had been mentioned for the Korean strain of $A$. poporum, but in low numbers $(<5)$ and in scattered arrangement (Potvin et al., 2012). The larger antapical plate for many species of Azadinium bears the antapical spine, but for the closely related species $A$. languida, it interestingly also bears a large conspicuous antapical pore. This pore of $A$. languida is bordered by a broad rim and is effectively a depressed field of small pores, the number of which has been described as about 15 , with each single pore having a diameter of about $0.1 \mu \mathrm{m}$ (Tillmann et al., 2012a). This is the same general size of small pores reported for species of Azadinium as well as that estimated here for the Argentinean isolates of $A$. poporum. A superficially similar field of small pores on the second antapical plate has been reported for the heterotrophic species Peridiniella danica (Mackenzie, 1991; Okolodkov and Dodge, 1995). In field samples this structure was reported to be present in some cells of Peridiniella only (Okolodkov and Dodge, 1995), although here conspecificity of the different $P$. danica types needs to be clarified.

It is concluded that there is a certain level of flexibility in cell size and shape, as well as shape and/or pore-pattern of some thecal plates, but major and stable diagnostic traits between the previously described strains of Azadinium poporum and the new South Atlantic isolates described here could not be identified. Thus, it is argued that they all belong to the same species.

\subsection{Phylogeny}

Molecular phylogeny likewise indicates that the Argentinean Azadinium strains belong to Azadinium poporum. Nevertheless, considerable differences in ITS and LSU rDNA gene sequences have been recorded for European and Asian isolates. In a previous LSU/ ITS tree (Gu et al., 2013), all available strains of $A$. poporum formed three well supported clades, one of them including multiple strains originating from the coast of China as well as the Korean strain (ribotype B). The second clade included strains from the East China Sea and South China Sea (ribotype C), and the third consisted of strains from Europe (ribotype A). Similar results were obtained in the present study using also ITS plus LSU sequences, and all Argentinean A. poporum isolates fell into ribotype $C$ in a highly supported clade. Within this clade all Argentinean isolates were distinct from Chinese ribotype $C$ isolates, but statistical values were low and not supportive of differentiation between Argentinean and Chinese strains. The slight differences in both ITS and LSU sequences between Chinese and Argentinean isolates likewise do not support genetic differentiation in terms of geographical origin. A much larger number of isolates from different areas, and analysis of other more variable marker genes would be needed to make more valid biogeographic inferences. Our data nevertheless 
suggest that Argentinean and Asian strains originated from a single ancestor species and that a dispersal link should exist between these two distant geographical areas.

\subsection{Toxins}

Diversity within the species Azadinium poporum in terms of morphological details as well as molecular ribotypes is also reflected by the considerable diversity within this species in terms of toxin profiles. Whereas all three available North Sea isolates only produce AZA-37 (compound 2 in Krock et al., 2012), A. poporum from the Asiatic Pacific region produces more complex AZA profiles including AZA-2, $-11,-36,-40,-41$ in different combinations, and also strains without any known AZA have been described (Gu et al., 2013; Krock et al., 2014). AZA-2 as the major AZA produced by the Argentinean isolates thus is in line with a close relation to the Asian clade of A. poporum, for which AZA-2 production was found in 7 out of 22 strains (Krock et al., 2014). In contrast to all Argentinean strains, 4 of the 7 Chinese isolates that produced AZA-2 concurrently produced AZA-36 in a relative stable ratio of about 6 to 1 (Krock et al., 2014). A feature which is shared among some Asian Pacific and all Argentinean isolates of $A$. poporum is the production of minor amounts of AZA-related compounds with higher molecular masses. Whereas A. poporum strain G25 from the Bohai Sea (North China) produces compounds $m / z 920$ and 928 (Gu et al., 2013), the Argentinean strains produce a compound $\mathrm{m} / \mathrm{z}$ 936 with similar CID fragmentation patterns (Fig. 9) as compound $\mathrm{m} / z$ 920. High resolution mass spectrometric analysis revealed that the compound $\mathrm{m} / \mathrm{z} 936$ contained one phosphorous atom, and the sum formula was consistent with AZA-2 phosphate, where probably one of the two hydroxyl groups of AZA-2 is esterified with a phosphate. This is particularly interesting, because to date no marine algal toxins containing phosphorous have been described. The relative abundance of the phosphate-containing compound seemed to be relatively low at approximately 3.5\%; however, this value is expressed as AZA-2 equivalent, which in this special case probably strongly underestimates the real proportion of AZA-2 phosphate. Compounds were quantified by the transition of the pseudomolecular ion $[\mathrm{M}+\mathrm{H}]^{+}$to the first water loss. Whereas this transition shows a high intensity in the case of AZA-2, it is only a weak transition of the phosphate (Fig. 9) and thus most likely underestimates the actual proportion of the phosphate of the AZA profile. The third AZA compound detected in the Argentinean strains is AZA-2 methyl ester, most likely an extraction artifact caused by the use of methanol as solvent (Jauffrais et al., 2012). It has been observed before that extraction and storage of AZA containing samples results in methylation of the carboxylic acid function of AZA (Jauffrais et al., 2012; Krock et al., 2012). The fact that AZA-2 methyl ester is only present as a minor component is consistent with this interpretation.

\subsection{Cysts}

We obtained Azadinium poporum cultures by incubating sediment samples that had been stored at $4{ }^{\circ} \mathrm{C}$ for more than two years, indicating that a cyst stage is highly probable. This conclusion is in line with the observations of Potvin et al. (2012) and Gu et al. (2013), who also used sediment incubation to obtain A. poporum cultures. A. dalianense likewise was recovered from long-term stored sediment samples (Luo et al., 2013). In the present study, all hatched Azadinium-like cells successfully brought into culture were A. poporum. The failure to detect other Azadinium species does not necessarily mean their absence along the Argentinean coast. Other species might not have cyst stages, might have different hatching preferences, or might not have survived the isolation procedure or just escaped detection.
An unambiguously identification of resting stages of Azadinium by microscopy failed, which might be due to a presumably small size and inconspicuous shape of such cysts. Among Amphidomataceae, cyst-like cells have previously been observed in cultures of two species, A. polongum (Tillmann et al., 2012b) and Azadinium poporum (Gu et al., 2013). In one out of 25 Chinese isolates of $A$. poporum, a few distinct cyst-like cells were observed and described as ellipsoid, about $15 \mu \mathrm{m}$ long and $10 \mu \mathrm{m}$ wide, and filled with pale granules and a yellow accumulation body. Likewise, cultured A. polongum has been described to produce round cyst-like cells of $10-16 \mu \mathrm{m}$ in diameter and with pale white inclusions. SEM failed to detect any external cyst structures such as paratabulation and/ or archeopyle, and hatching was not observed. To date an induction of cyst formation in the cultures of Argentinean A. poporum has failed, but clearly more targeted experiments, data, and observations are needed to clarify the life cycle of Azadinium and to establish cyst-theca relationships for species of Azadinium.

\subsection{Field situation}

During the cruise in spring 2010 vegetative Azadinium poporum (or any Azadinium-like cells) in the water column and AZA toxins in the small plankton fraction were not detected. Previous South Atlantic blooms of Azadinium have been described to occur in spring or even in late winter (Akselman and Negri, 2012; Akselman et al., 2014), but these blooms refer to another species (Azadinium cf. spinosum), and occurred farther offshore along extensive areas of the middle shelf and near the shelf break (Akselman and Negri, 2012; Akselman et al., 2014). Coastal populations of A. poporum, however, may have a different seasonality. A more detailed investigation on the seasonal and interannual variability of Azadinium spp. conducted at a fixed station close to the Argentinean coast (Akselman et al., 2014) from 1994 to 2000 revealed Azadinium to be present in all years but in low abundance and sporadically. Nevertheless, whereas the offshore blooms of $A$. cf. spinosum occurred in spring at low water temperature $\left(<10^{\circ} \mathrm{C}\right)$, Azadinium spp. at the coastal station was recorded during the warm periods in summer and autumn as well (Akselman et al., 2014) which might indicate the presence of several species of Azadinium with different ecological requirements in Argentinean waters.

Even in the absence of Azadinium and/or AZA toxins in the water column, the present study demonstrates the potential of benthic cysts of Azadinium poporum to inoculate the water column in the ER estuarine system. The presence of cysts moreover indicates the presence of established $A$. poporum populations in the area. A spatial relationship between bloom population patches and areas where cysts are deposited is complex and depends on the interplay between sedimentation rate and the hydrographic situation. For the shallow frontal system of the ER estuarine system, the oceanographic data collected during the expedition were consistent with the description of three hydrographical zones reported by Guerrero (1998) for this region. Low salinity coastal waters (LSCW) become diluted by feshwater input from the Colorado and Negro Rivers (Fig. 1). Between the coastal and shelf waters, a saline front oriented meridionally to the coastline separates LSCW from an area with a salinity maximum (Saline Front Waters, SFW) (Guerrero, 1998; Lucas et al., 2005; Martos et al., 2005; Auad and Martos, 2012). This salinity maximum originates in the San Matías Gulf (SMG), due to the dominance of evaporation over precipitation (Lucas et al., 2005). The most external sector corresponds to a second, weaker front to the east of the absolute salinity maximum, resulting from its meeting with relatively cooler shelf waters of intermediate salinity (Middle Shelf Waters, MSW) advected from the south. The transect of stations perpendicular to the coast thus included stations representative for all three waters masses 
(Sta. 26: LSCW, Sta 22 and 28: SFW; Sta 18: MSW), and a marked increase in cysts at station 18 was found (Fig. 3), corresponding to a high number of $A$. poporum isolates obtained from this station. This is likely related to a thermal stratification observed at this site (Fig. 2B). Such a seasonal stratification has been ascribed to heating of the superficial water during the Austral spring such that it reaches the inner zone (with only 30-40 m water depth) at $50 \mathrm{~km}$ from the coast (Lucas et al., 2005). It probably is responsible for creating environmental conditions that favour dinoflagellate blooms (Smayda, 1997).

\section{Conclusion}

The first record of an azaspiracid-producing species of Azadinium from the South Atlantic is presented. Isolation of cells from sediment samples after long-term storage is evidence for the presence of cysts and indicates that Azadinium poporum populations are well established in that area with the latent potential to recurrently inoculate vegetative plankton populations and to initiate blooms. This is consistent with the fact that occurrence of AZA-2 in shellfish (Brachidontes rodriguezii and Mesodesma mactroides) in Argentina has been recently reported (Turner and Goya, 2015). In this region, natural beds of Zygochlamys patagonica (Patagonian scallop) which are spread along the continental shelf (Bogazzi et al., 2005) are commercially exploited. In addition, wild beds of mollusks from intertidal and subtidal zones, have been traditionally harvested by fishermen and some companies have begun to improve the culture of oysters and mussels along the coast from the South of Buenos Aires, North Patagonian Gulfs and Tierra del Fuego (Medina et al., 2011). Thus, more data on the spatio-temporal distribution of $A$. poporum and other species of Amphidomataceae, as well as on the presence of $A Z A$, are needed in order to fully evaluate the risk potential of AZA shellfish contamination episodes in the Southwestern Atlantic region.

\section{Acknowledgement}

We greatly acknowledge the help of Wolfgang Drebing (AWI) for analyses of azaspiracids and of Nancy Kühne (AWI) for DNA extraction and sequencing of the Azadinium poporum isolates. We thank Steve Pueppke for correcting the English. This work was partially financed by the binational project MINCyT-BMBF (AL/11/ 03-ARG 11/021) and supported by PIP 00173 (CONICET) grant and by the European Commission under the $7^{\text {th }}$ Framework Programme through the Action - IMCONet (FP7 IRSES, action no. 319718). Additional financial support was provided by the PACES research program of the Alfred Wegener Institute as part of the Helmholtz Foundation initiative in Earth and Environment. NT was supported by Fondecyt Grant \# 11121554. C.M.B. was supported by PIP CONICET 11420100100234 . We thank R. Reta (INIDEP) and crews of RV/BOPD (CONICET-MINDEF) for the assistance during the cruise.[SS]

\section{Appendix A. Supplementary data}

Supplementary material related to this article can be found, in the online version, at doi:10.1016/j.hal.2015.11.001.

\section{References}

Adachi, M., Sako, Y., Ishida, Y., 1996. Analysis of Alexandrium (Dinophyceae) species using sequences of the $5.8 \mathrm{~S}$ ribosomal DNA and internal transcribed spacer regions. J. Phycol. 32, 424-432.

Akselman, R., Negri, A., 2012. Blooms of Azadinium cf. spinosum Elbrächter et Tillmann (Dinophyceae) in northern shelf waters of Argentina, Southwestern Atlantic. Harmful Algae 19, 30-38.
Akselman, R., Negri, R.A., Cozzolino, E., 2014. Azadinium (Amphidomataceae Dinophyceae) in the Southwest Atlantic: In situ and satellite observations. Rev. Biol. Mar. Oceanogr. 49, 511-526.

Álvarez, G., Uribe, E., Avalos, P., Marino, C., Blanco, J., 2010. First identification of azaspiracid and spirolides in Mesodesma donacium and Mulinia edulis from Northern Chile. Toxicon 55, 638-641.

Amzil, Z., Sibat, M., Royer, F., Savar, V., 2008. First report on azaspiracid and yessotoxin groups detection in French shellfish. Toxicon 52, 39-48.

Auad, G., Martos, P., 2012. Climate variability of the northern Argentinean shelf circulation: impact on Engraulis anchoita. Int. J. Ocean Clim. Syst. 3, 17-43.

Bogazzi, E., Baldoni, A., Rivas, A., Martos, P., Reta, R., Orensanz, J.M., Lasta, M. Dell'Arciprete, P., Werner, F., 2005. Spatial correspondence between areas of concentration of Patagonian scallop (Zygochlamys patagonica) and frontal systems in the southwestern Atlantic. Fish. Oceanogr. 14, 359-376.

Bolch, C.J.S., 1997. The use of sodium polytungstate for the separation and concentration of living dinoflagellate cysts from marine sediments. Phycologia 36, $472-478$.

Braña Magdalena, A., Lehane, M., Krys, S., Fernández, M.L., Furey, A., James, K.J., 2003. The first identification of azaspiracids in shellfish from France and Spain. Toxicon 42, 105-108.

Edgar, R.C., 2004. MUSCLE: multiple sequence alignment with high accuracy and high throughput. Nucleic Acids Res. 32, 1792-1797.

Elgarch, A., Vale, P., Rifai, S., Fassouane, A., 2008. Detection of diarrheic shellfish poisoning and azaspiracid toxins in Moroccan mussels: comparison of the LCMS method with the commercial immunoassay kit. Mar. Drugs 6, 587-594.

Fensome, R.A., Taylor, F.J.R., Norris, G., Sarjeant, W.A.S., Wharton, D.I., Williams, G.L., 1993. A classification of living and fossil dinoflagellates. Micropaleontol. Spec. Pub. 7, 1-351.

Fritz, L., Triemer, R.E., 1985. A rapid simple technique utilizing Calcofluor white M2R for the visualization of dinoflagellate thecal plates. J. Phycol. 21, 662-664.

Furey, A., Moroney, C., Magdalena, A.B., Saez, M.J.F., Lehane, M., James, K.J., 2003. Geographical, temporal, and species variation of the polyether toxins, azaspirazids, in shellfish. Environ. Sci. Technol. 37, 3078-3084.

Glibert, P.M., Anderson, D., Gentien, P., Granéli, E., Sellner, K., 2005. The global, complex phenomena of Harmful Algal blooms. Oceanography 18, 136-147.

Gu, H., Luo, Z., Krock, B., Witt, M., Tillmann, U., 2013. Morphology, phylogeny and azaspiracid profile of Azadinium poporum (Dinophyceae) from the China Sea. Harmful Algae 21-22, 64-75

Guerrero, R.A., 1998. Oceanografía física del estuario del Río de la Plata y el sistema costero de El Rincón Noviembre, 1994. INIDEP Informe Técnico 21, 29-54.

Hess, P., McCarron, P., Krock, B., Kilkoyne, J., Miles, C.O., 2014. Azaspiracids: chemistry, biosynthesis, metabolism and detection. In: Botana, L.M. (Ed.) Seafood and Freshwater Toxins. CRC Press, Boca Raton, USA, pp. 799-821.

Huelsenbeck, J., Ronquist, F., 2001. MRBAYES: Bayesian inference of phylogenetic trees. Bioinformatics 17, 754-755.

James, K.J., Furey, A., Lehane, M., Ramstad, H., Aune, T., Hovgaard, P., Morris, P. Higman, W., Satake, M., Yasumoto, T., 2002. First evidence of an extensive northern European distribution of azaspirazid poisoning (AZP) toxins in shellfish. Toxicon 40, 909-915.

Jauffrais, T., Herrenknecht, C., Séchet, V., Sibat, M., Tillmann, U., Krock, B., Kilcoyne, J., Miles, C.O., McCarron, P., Amzil, Z., Hess, P., 2012. Quantitative analysis of azaspiracids in Azadinium spinosum cultures. Anal. Bioanal. Chem. 403, 833-846.

Keller, M.D., Selvin, R.C., Claus, W., Guillard, R.R.L., 1987. Media for the culture of oceanic ultraphytoplankton. J. Phycol. 23, 633-638.

Kimura, M., 1980. A simple method for estimating evolutionary rate of base substitutions through comparative studies of nucleotide sequences. J. Mol. Evol. 16, 111-120.

Krock, B., Tillmann, U., John, U., Cembella, A.D., 2009. Characterization of azaspiracids in plankton size-fractions and isolation of an azaspiracid-producing dinoflagellate from the North Sea. Harmful Algae 8, 254-263.

Krock, B., Tillmann, U., Voß, D., Koch, B.P., Salas, R., Witt, M., Potvin, E., Jeong, H.J., 2012. New azaspiracids in Amphidomataceae (Dinophyceae): proposed structures. Toxicon 60, 830-839.

Krock, B., Tillmann, U., Witt, M., Gu, H., 2014. Azaspiracid variability of Azadinium poporum (Dinophyceae) from the China Sea. Harmful Algae 36, 22-28.

López-Rivera, A., O'Callaghan, K., Moriarty, M., O’Driscoll, D., Hamilton, B., Lehane, M., James, K.J., Furey, A., 2010. First evidence of azaspiracids (AZAs): a family of lipophilic polyether marine toxins in scallops (Argopecten purpuratus) and mussels (Mytilus chilensis) collected in two regions of Chile. Toxicon 55, $692-701$.

Lucas, A.J., Guerrero, R.A., Mianzán, H.W., Acha, E.M., Lasta, C.A., 2005. Coastal oceanographic regimes of the Northern Argentine Continental Shelf (34-43 ${ }^{\circ}$ ). Estuar. Coast. Shelf Sci. 65, 405-420.

Luo, Z., Gu, H., Krock, B., Tillmann, U., 2013. Azadinium dalianense, a new dinoflagellate from the Yellow Sea, China. Phycologia 52, 625-636.

Mackenzie, L., 1991. Toxic and noxious phytoplankton in Big Glory Bay, Stewart Island, New Zealand. J. Appl. Phycol. 3, 19-34.

Martos, P., Hansen, J.E., Negri, R.M., Madirolas, A., 2005. Factores Oceanográficos relacionados con la abundancia relativa de anchoíta sobre la plataforma bonaerense $\left(34^{\circ}-41^{\circ} \mathrm{S}\right)$ durante la primavera. Rev. Investig. Desarrollo Pesquero $17,5-33$.

McMahon, T., Silke, J., 1996. West coast of Ireland; winter toxicity of unknown aetiology in mussels. Harmful Algae News 14, 2.

Medina, D., Goya, A.B., Rozas, C., 2011. Molluscan shellfish safety in South America. In: GS. (Eds.), Molluscan Shellfish Safety. Springer, Dordrecht/Heidelberg/New York, pp. 39-46. 
Nicolaou, K.C., Frederick, M.O., Pertovic, G., Cole, K.P., Loizidou, E.Z., 2006. Total synthesis and confirmation of the revised structures of azaspirazid-2 and azaspirazid-3. Angew. Chem. Int. Ed. 45, 2609-2615.

Okolodkov, Y.B., Dodge, J.D., 1995. Redescription of the planktonic dinoflagellate Peridiniella danica (Paulsen) comb. nov. and its distribution in the N.E. Atlantic. Eur. J. Phycol. 30, 299-306.

Percopo, I., Siano, R., Rossi, R., Soprano, V., Sarno, D., Zingone, A., 2013. A new potentially toxic Azadinium species (Dinophyceae) from the Mediterranean Sea, A. dexteroporum sp. nov. J. Phycol. 49, 950-966.

Pfiester, L.A., Anderson, D.M., 1987. Dinoflagellate reproduction. In: Taylor, F.J.R. (Ed.), The Biology of Dinoflagellates. Academic Press, New York, pp. 611-648.

Potvin, E., Jeong, H.J., Kang, N.S.T., Tillmann, U., Krock, B., 2012. First report of the photosynthetic dinoflagellate genus Azadinium in the Pacific Ocean: Morphology and molecular characterizationof Azadinium cf. poporum. J. Eukaryot. Microbiol. 59, 145-156.

Proenca, L., Schramm, M., de Sandos, K., Martin, H., Alves, T., Menezes, M., 2014 Azaspiracid production by an Azadinium like flagellate isolated from a shallow mixohaline mangrove system at southern Brazilian coast. In: Abstract Book of the 16th International Conference on Harmful Algae, New Zealand, p. 24.

Salas, R., Tillmann, U., John, U., Kilcoyne, J., Burson, A., Cantwell, C., Hess, P., Jauffrais, T., Silke, J., 2011. The role of Azadinium spinosum (Dinophyceae) in the production of Azasdpiracid Shellfish Poisoning in mussels. Harmful Algae 10, 774-783.

Satake, M., Ofuji, K., James, K., Furey, A., Yasumoto, T., 1998. New toxic events caused by Irish mussels. In: Reguera, B., Blanco, J., Fernandez, M.L., Wyatt, T. (Eds.), Harmful Algae. Xunta de Galicia and Interantional Oceanographic Commission of UNESCO, Santiago de Compostela, pp. 468-469.

Schiller, J. (Ed.), 1937. Dinoflagellatae (Peridineae) in monographischer Behandlung. Johnson, New York.

Scholin, C.A., Herzog, M., Sogin, M., Anderson, D.M., 1994. Identification of groupand strain-specific genetic markers for globally distributed Alexandrium (Dinophyceae). II. Sequence analysis of a fragment of the LSU rRNA gene. J. Phycol. 30, 999-1011.

Smayda, T.J., 1997. Harmful algal blooms: their ecophysiology and general relevance to phytoplankton blooms in the sea. Limnol. Oceanogr. 42, 1137-1153.

Smith, K.F., Rhodes, L., Harwood, D.T., Adamson, J., Moisan, C., Munday, R., Tillmann, U., 2015. Detection of Azadinium poporum in New Zealand: the use of molecular tools to assist with species isolations. J. Appl. Phycol., http://dx.doi.org/10.1007/ s10811-015-0667-5.

Stockmarr, J., 1971. Tablets with spores used in absolute pollen analysis. Pollen Spores 13, 615-621.

Taleb, H., Vale, P., Amanhir, R., Benhadouch, A., Sagou, R., Chafik, A., 2006. First detection of azaspirazids in mussels in north west Africa. J. Shellf. Res. 25, 1067-1070.

Tamura, K., Stecher, G., Peterson, D., Filipski, A., Kumar, S., 2013. MEGA6: Molecular Evolutionary Genetics Analysis version 6.0. Mol. Biol. Evol. 30, 2725-2729.

Tavaré, S., 1986. Some probabilistic and statistical problems in the analysis of DNA sequences. Lect. Math. Life Sci. (Am. Math. Soc.) 17, 57-86.
Tillmann, U., Elbrächter, M., Krock, B., John, U., Cembella, A., 2009. Azadinium spinosum gen. et sp. nov (Dinophyceae) identified as a primary producer of azaspiracid toxins. Eur. J. Phycol. 44, 63-79.

Tillmann, U., Elbrächter, M., John, U., Krock, B., Cembella, A., 2010. Azadinium obesum (Dinophyceae), a new nontoxic species in the genus that can produce azaspiracid toxins. Phycologia 49, 169-182.

Tillmann, U., Elbrächter, M., John, U., Krock, B., 2011. A new non-toxic species in the dinoflagellate genus Azadinium: A. poporum sp. nov. Eur. J. Phycol. 46 74-87.

Tillmann, U., Salas, R., Gottschling, M., Krock, B., ÓDriscoll, D., Elbrächter, M., 2012a. Amphidoma languida sp. nov (Dinophyceae) reveals a close relationship between Amphidoma and Azadinium. Protist 163, 701-719.

Tillmann, U., Söhner, S., Nézan, E., Krock, B., 2012b. First record of Azadinium from the Shetland Islands including the description of A. polongum sp. nov. Harmful Algae 20, 142-155.

Tillmann, U., Gottschling, M., Nézan, E., Krock, B., Bilien, G., 2014a. Morphological and molecular characterization of three new Azadinium species (Amphidomataceae, Dinophyceae) from the Irminger Sea. Protist 165, 417-444.

Tillmann, U., Krock, B., Taylor, B., 2014b. Azadinium caudatum var. margalefii, a poorly known member of the toxigenic genus Azadinium (Dinophyceae). Mar. Biol. Res. 10, 941-956.

Tillmann, U., Salas, R., Jauffrais, T., Hess, P., Silke, J., 2014c. AZA: the producing organisms - biology and trophic transfer. In: Botana, L.M. (Ed.), Seafood and Freshwater Toxins. CRC Press, Boca Raton, USA, pp. 773-798.

Torgersen, T., Bruun Bremmens, N., Rundberget, T., Aune, T., 2008. Structural confirmation and occurence of azaspiracids in Scandinavian brown crabs (Cancer pagurus). Toxicon 51, 93-101.

Trainer, V.L., Moore, L., Bill, B.D., Adams, N.G., Harrington, N., Borchert, J., Da Silva, D.A.M., Eberhard, B.T.L., 2013. Diarrhetic shellfish toxins and other lipophilic toxins of human health concern in Washington State. Mar. Drugs $11,1815-1835$

Trefault, N., Krock, B., Delherbe, N., Cembella, A., Vásquez, M., 2011. Latitudinal transects in the southeastern Pacific Ocean reveal a diverse but patchy distribution of phycotoxins. Toxicon 58, 389-397.

Turner, A.D., Goya, A.B., 2015. Occurrence and profiles of lipophilic toxins in shellfish harvested from Argentina. Toxicon 102, 32-42.

Twiner, M., Hess, P., Doucette, G.J., 2014. Azaspiracids: toxicology, pharmacology, and risk assessment. In: Botana, L.M. (Ed.), Seafood and Freshwater Toxins. CRC Press, Boca Raton, USA, pp. 823-855.

Ueoka, R., Ito, A., Izumikawa, M., Maeda, S., Takagi, M., Shin-Ya, K., Yoshida, M., van Soest, R.W.M., Matsunaga, S., 2009. Isolation of azaspiracid-2 from a marine sponge Echinoclathria sp as a potent cytotoxin. Toxicon 53, 680-684.

Utermöhl, H., 1958. Zur Vervollkommnung der quantitativen Phytoplankton-Methodik. Mitt. Int. Ver. Theor. Angew. Limnol. 9, 1-38.

Yao, J., Tan, Z., Zhou, D., Guo, M., Xing, L., Yang, S., 2010. Determination of azaspiracid-1 in shellfishes by liquid chromatography with tandem mass spectrometry. Chin. J. Chromatogr. 28, 363-367. 